\title{
Recent Advances in Applications of Hybrid Graphene Materials for Metals Removal from Wastewater
}

\author{
Abdulrahman Abu-Nada ${ }^{1}$, Gordon McKay ${ }^{1, *}$ and Ahmed Abdala ${ }^{2, * \mathbb{D}}$ \\ 1 Division of Sustainable Development, College of Science and Engineering, Hamad Bin Khalifa University, \\ PO Box 34110, Doha, Qatar; aabunada@mail.hbku.edu.qa \\ 2 Chemical Engineering Program, Texas A\&M University at Qatar, POB 23874, Doha, Qatar \\ * Correspondence: gmckay@hbku.edu.qa (G.M.); ahmed.abdala@qatar.tamu.edu (A.A.); \\ Tel.: +974-4423-0180 (A.A.)
}

Received: 5 February 2020; Accepted: 24 February 2020; Published: 24 March 2020

check for updates

\begin{abstract}
The presence of traces of heavy metals in wastewater causes adverse health effects on humans and the ecosystem. Adsorption is a low cost and eco-friendly method for the removal of low concentrations of heavy metals from wastewater streams. Over the past several years, graphene-based materials have been researched as exceptional adsorbents. In this review, the applications of graphene oxide (GO), reduce graphene oxide (rGO), and graphene-based nanocomposites (GNCs) for the removal of various metals are analyzed. Firstly, the common synthesis routes for GO, rGO, and GNCs are discussed. Secondly, the available literature on the adsorption of heavy metals including arsenic, lead, cadmium, nickel, mercury, chromium and copper using graphene-based materials are reviewed and analyzed. The adsorption isotherms, kinetics, capacity, and removal efficiency for each metal on different graphene materials, as well as the effects of the synthesis method and the adsorption process conditions on the recyclability of the graphene materials, are discussed. Finally, future perspectives and trends in the field are also highlighted.
\end{abstract}

Keywords: graphene nanocomposites; heavy metals; adsorption; regeneration

\section{Introduction}

Both natural and anthropogenic sources linked to industrial activities such as electroplating, metal smelting, fertilizer industries, mining operations, pesticides, and paper manufacturing result in wastewater streams contaminated with various heavy metals. Discharging these streams into the environment leads to the absorption and accumulation of heavy metals into living organisms resulting in severe health complications. Therefore, the current stringent regulations, requires the removal of heavy metal from wastewater streams to extremely low levels. The WHO guideline [1] for the quality of drinking water restricts the concentrations of heavy metal to a fraction of $\mathrm{mg} / \mathrm{L}$, as shown in Table 1 .

Table 1. WHO guideline for metal concentration in drinking water quality.

\begin{tabular}{cccccccc}
\hline Metal & $\mathbf{C u}$ & $\mathbf{C r}$ & $\mathbf{C d}$ & $\mathbf{H g}$ & $\mathbf{P b}$ & As & Ni \\
\hline $\begin{array}{c}\text { Permissible } \\
\text { limit, } \mu \mathrm{g} / \mathrm{L}\end{array}$ & 2000 & 50 & 3 & 3 & 10 & 10 & 700 \\
\hline
\end{tabular}

Several technologies are being used or proposed for removing heavy metals from wastewater streams including chemical precipitation [2], ion exchange [3], membrane filtration [4], flotation [5], electrochemical coagulation treatment [6], and adsorption. Among these methods, adsorption has the advantage of process flexibility, low cost, and the ability to reduce the heavy metal to the required 
low level, making it the preferred treatment method for heavy metal removal [7]. Both conventional adsorbents such as activated carbon [8,9] and nanoadsorbents including carbon nanotubes [10,11], chitosan [12], and nanocellulose [13] are candidates for heavy metal removal. Recently, graphenebased materials are being explored and proved to be efficient nanoadsorbents for the removal of heavy metals as shown by the number of publications on "graphene metal removal" that increased from 2 publications in 2012 to 102 publications in 2019 with the majority of these publications on removal of copper and chromium as indicated in Figure 1.

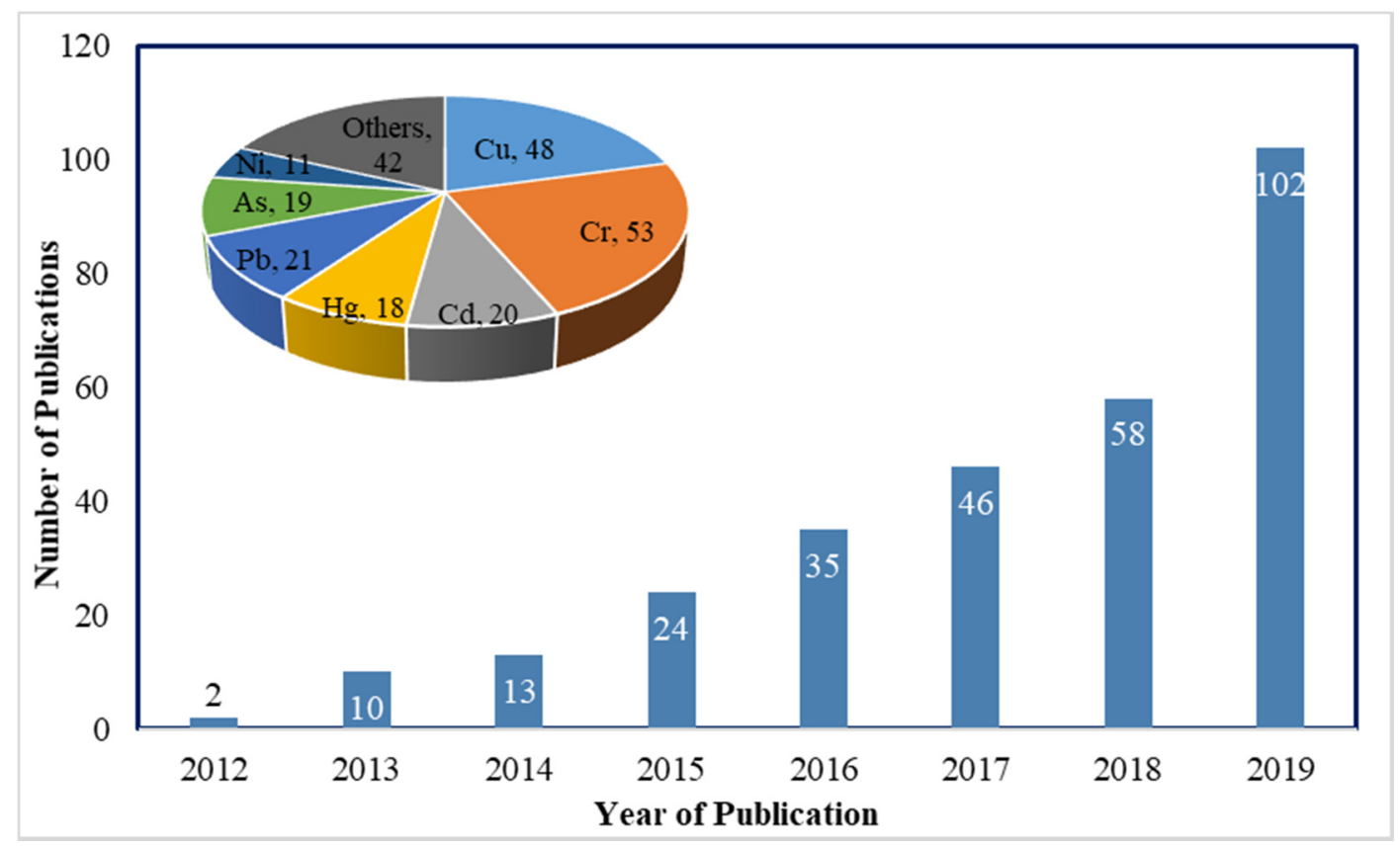

Figure 1. Annual publications returned using "graphene" and "metal removal" as keywords from ScienceDirect. Inset: the number of publications on removal of specific metals.

Although graphene can be prepared by bottom up approaches such as CVD, epitaxial growth, templating, and organic synthesis, graphene materials used in adsorption applications are prepared by top-down methods via oxidation of graphite to produced graphene oxide (GO) that can be thermally or chemically reduced to obtain reduced graphene oxide (rGO). Further modification of GO and rGO via the development of nanocomposites with metal oxides and organic molecules enhances their sorption characteristics.

This review focuses on the removal of heavy metals from wastewater using various graphene materials. Although there are already few articles that review the adsorption of various metals on graphene materials, this article is more comprehensive and it also accounts for the large number of very recent articles appeared in 2018 and 2019, which represent about $60 \%$ of the total number of publications. Moreover, this review includes a concise section on the synthesis of various graphene materials and composites in order to classify the various graphene materials and establish the correlation between the synthesis method, structure, and the adsorption characteristics of the graphene materials. Moreover, the key adsorption parameters associated with each metal on various graphene-based materials are summarized in tables and the performance of the key graphene materials are highlighted and discussed.

It is very evident that application of graphene materials as adsorbents for metal removal is a rapidly growing research field as can be seen by the very large increase in number of publications in 2018 and 2019, Figure 1. The adsorptive properties of graphene can be applied in many forms, e.g., sheets, nanotubes, 3D structures, and membranes [14]. These forms have been utilized in water purifications for removal of a variety of contaminants such as heavy metals, different dyes, pharmaceuticals, and 
organics [15]. It is also worth noting that this review focuses on the adsorptive removal of heavy metal and the use of graphene-based membranes for removal of heavy metals is beyond its scope.

This review begins with a concise discussion on the synthesis of GO, $\mathrm{rGO}$ and their nanocomposites with organic, inorganic, and polymers, which have been used for metal removal. Then an overview of the typical methodology to study adsorption and the models used for analysis of the process thermodynamics and kinetics are provided and a comprehensive analysis of the performance of various graphene-based materials for the adsorption of various metals is carried. Finally, an outline of the major challenges for the commercialization of graphene-based adsorbents for heavy metals and highlights the future research directions are presented.

\section{Graphene-Based Materials for Removal of Heavy Metals}

The graphene materials used for the removal of heavy metals are classified into two broad categories that include:

1. GO and rGO and their foam/aerogel structures and

2. Hybrid of GO or rGO with metallic, organic, inorganic, and polymeric materials

While there are few studies on the use GO and rGO in powder, aerogel, and 3D foam structure, most of the reports are on using hybrids of GO and rGO with organic, inorganic, and/or polymers. In this section, we summarize the synthesis methods for GO, rGO and hybrid graphene materials.

\subsection{Graphene Oxide and Reduced Graphene Oxide}

Although graphene can be obtained directly from graphite using mechanical cleavage or solution assisted exfoliation, the dominant type of graphene used in adsorption application is prepared via the graphite oxide route not only because its potential for large scale production, but also because it produces a functional form of graphene that is attractive for adsorption applications. In this route, GO is produced by exfoliation of graphite powder, which is produced through solution oxidation/intercalation of graphite using acids and oxidants. The first report on the synthesis of graphite dates back to 1958 by Brodie using nitric acid and potassium chlorate [16]. Currently, the most widely used methods in the preparation of graphite powder are the Hummer's method [17], modified Hummer's method [18], and Tour's method [19]. GO maintains the layered structure of graphite but with expanded interlayer separation due to the presence of polar oxygen groups such as hydroxyl, epoxy, carbonyl, and carboxylic. The introduction of these groups changes the carbon hybridization from $\mathrm{sp}^{2}$ in graphite to a mixture of $\mathrm{sp}^{2}$ and $\mathrm{sp}^{3}$ in GO. The oxygen content of graphite oxide is defined by the $\mathrm{C} / \mathrm{O}$ ratio which ranges between 1:1 in highly oxidized GO to 4:1 in less oxidized GO depending on the oxidation method and conditions. The presence of these oxygen groups makes graphite oxide very hydrophilic such that it readily exfoliates to GO in aqueous solution. rGO is prepared by thermal, hydrothermal, or chemical reduction of graphite oxide or GO. The reduction of GO to $\mathrm{rGO}$ reduced the oxygen content to about $\mathrm{C} / \mathrm{O}$ ratio of 10 . The structure of $\mathrm{GO}$ and $\mathrm{rGO}$ as well as the schematic for their preparation is shown in Figure 2 [20]. 


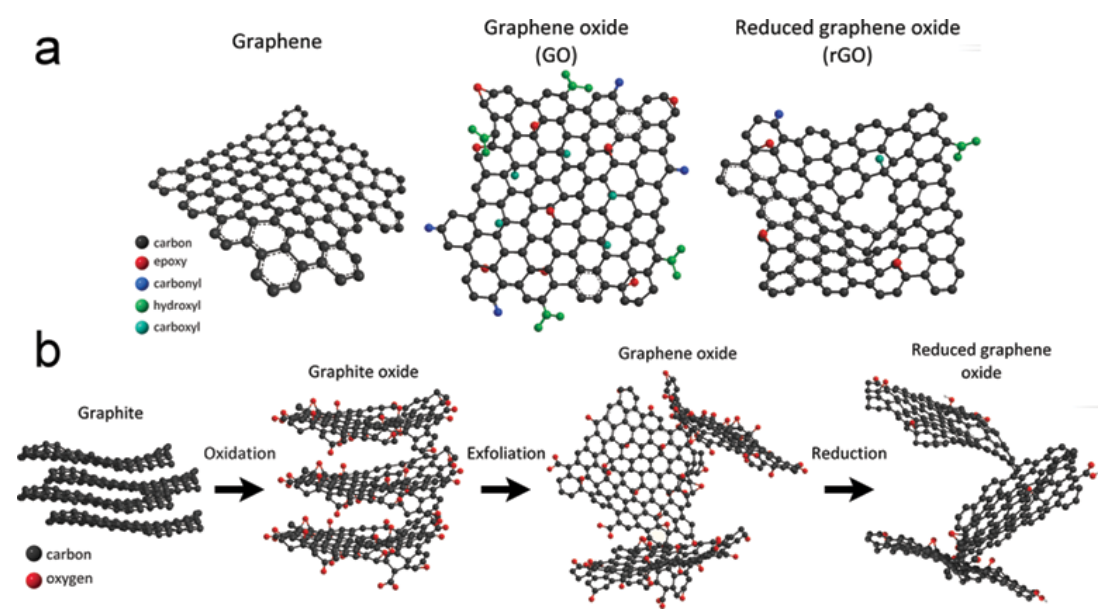

Figure 2. (a) Chemical structure of graphene (G), graphene oxide (GO), and reduced graphene oxide $(\mathrm{rGO})$ and $(\mathbf{b})$ route of graphite to reduce graphene oxide.(Reproduced or adapted from ref. [20], with permission from Intech, 2016).

Alazmi et al. [21] investigated the changes in the morphology of GO based on the oxidation method and the structure morphologies of rGO prepared by thermal, chemical, and hydrothermal reduction are probed by SEM and TEM analysis as shown in Figure 3.

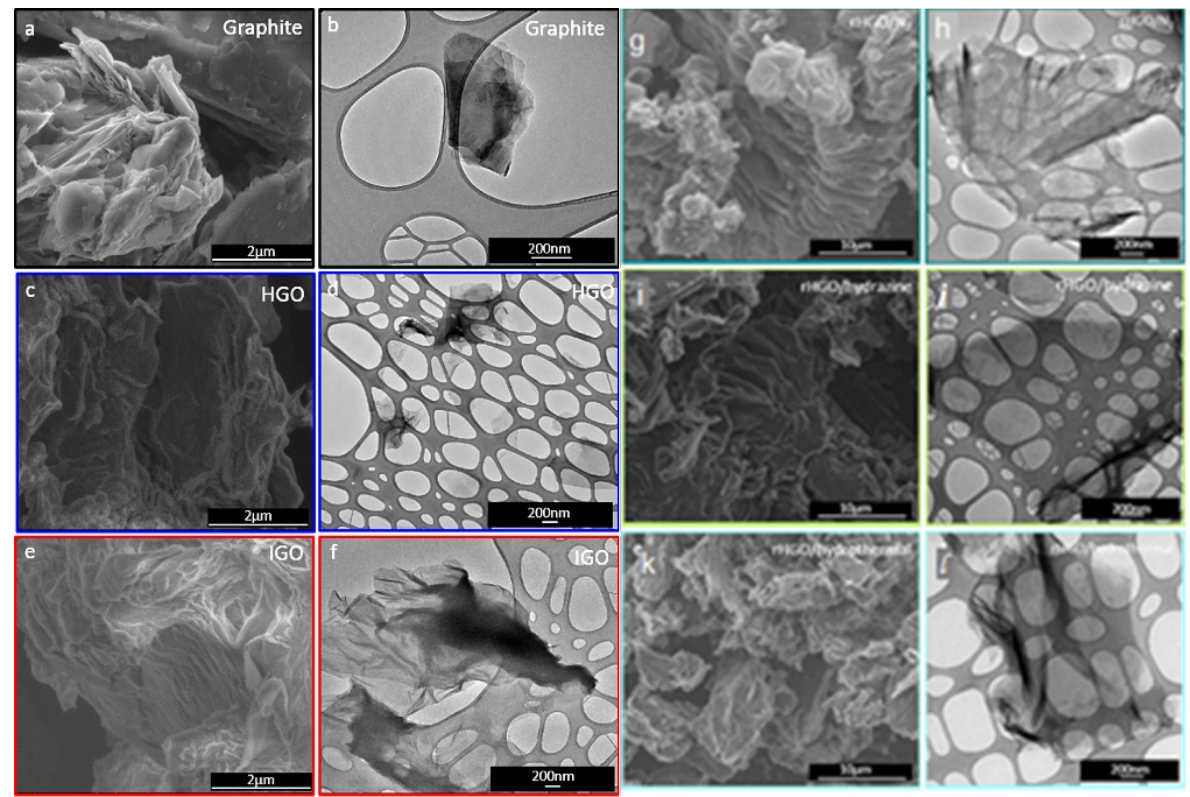

Figure 3. (a) SEM and (b) TEM of graphite, (c) SEM and (d) TEM of GO produced by Hummer's Method, (e) SEM and (f) TEM of GO produced by improved Hummer's method, (g) SEM and (h) TEM of rGO produced by thermal reduction in $\mathrm{N}_{2}$, (i) SEM and (j) TEM of rGO produced by chemical reduction using hydrazine, and (k) SEM and (1) TEM of rGO produced by solvothermal method. (Reproduced or adapted from ref. [21], with permission from Elsevier, 2020.)

In addition to microscopic characterization of GO and $\mathrm{rGO}$, characterization using spectroscopic techniques such as XPS and FTIR and diffraction techniques such as XRD and SAD are commonly used to determine the structure of GO and $\mathrm{rGO}$ and the presence of oxygen-containing functional compounds. Other characterization techniques have been performed. The synthesis of the adsorbents was been carried out with a variety of methods and with great rigor and control. Heat treatment at different temperature ranges, vacuum promoted exfoliation, physical incorporation of additives, and surface modifications using oxidative agents are a few techniques used in the synthesis processes [14]. 
For more details on the synthesis and characterization of GO and rGO, we refer the reader to the excellent and concise review article by Park and Ruoff [22].

\subsection{Graphene Composites for Adsorption Applications}

To improve the adsorption characteristics of GO and rGO and to enable their effective application in selective adsorption of heavy metals, a few strategies are applied. These strategies include the formation of hybrid structures of GO or rGO with oxides of transition metals such as iron, $\mathrm{Zn}, \mathrm{Cu}$, $\mathrm{Ni}$, and $\mathrm{Co}$, organic materials such as cellulose and chitosan, inorganic materials including metal organic framework (MOF), zeolites, and silica nanostructure, polymers and mixtures of two or more of these groups. Among these strategies, the development of magnetic nanocomposites of GO and rGO with $\mathrm{Fe}_{3} \mathrm{O}_{4}$ are very commonly applied not only to enhance the adsorption characteristics, but also to allow the retrieval of the adsorbent for regeneration at the end of the batch adsorption using magnetic recovery. Nevertheless, many studies have further modified the magnetic GO or rGO with other metallic, organic or inorganic materials. A concise review of the synthesis of these different hybrid graphene materials applied for the adsorption of heavy metals is provided.

\subsubsection{Magnetic Nanocomposites and Nanocomposites with Other Metals}

One of the significant challenges faced when using nanosorbents is their separation from the treated solution. Centrifugation, sedimentation, filtration, and other traditional separation methods deem to be ineffective and time consuming. On the other hand, magnetic GO (mGO) is synthesized via impregnation or co-precipitation methods [23-27] and can be easily separated by the aid of magnetic materials like $\mathrm{Fe}_{3} \mathrm{O}_{4}$ or $\mathrm{Fe}_{3} \mathrm{~S}_{4}$. $\mathrm{mGO}$ is synthesized via impregnation or co-precipitation methods [23-27]. In the co-precipitation method, $\mathrm{mGO}$ is synthesized via the hydrothermal process by an in-situ reduction/decomposition of a metal precursor such as $\mathrm{Fe}_{3} \mathrm{O}_{4}, \mathrm{FeSO}_{4}, \mathrm{Fe}(\mathrm{NO})_{3}$, or iron acetate on the surface of dispersed GO under sonication, see Figure 4. This step is frequently followed by an annealing step to enhance the crystal structure of the magnetic nanoparticle and induce complete reduction of GO to rGO. In addition, mGO could also enhance the adsorption of heavy metal ions but the calcination step may have a negative effect on the sorption properties as reducing GO tend to decrease the content of the oxygen functional groups, which in turn decreases the number of binding sites on the surface of the mGO.

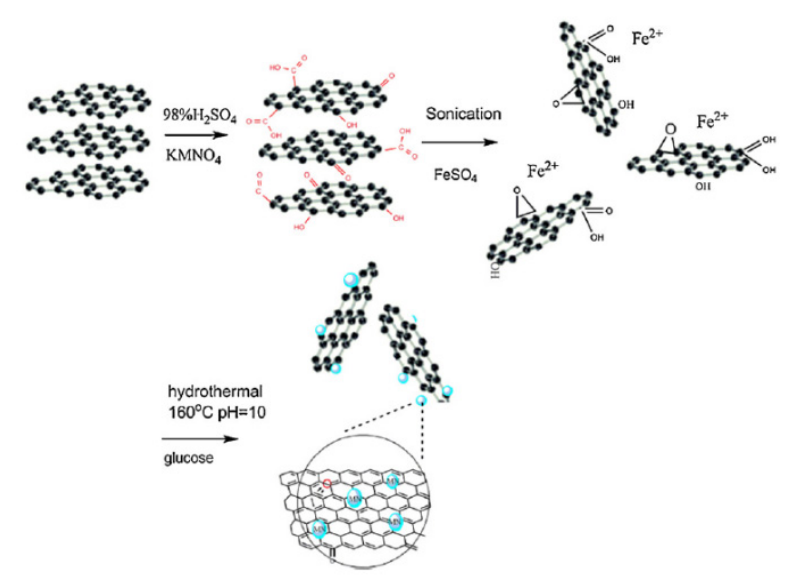

Figure 4. Synthesis of magnetic GO nanocomposite via precipitation method. (Reproduced or adapted from ref. [28], with permission from Elsevier, 2020).

In the impregnation method, a GO suspension is mixed with pre-synthesized magnetic nanoparticles and sonicated at room temperature until a homogenous suspension is achieved. The mGO is then collected by centrifugation followed by freeze-drying, Figure 5 . 


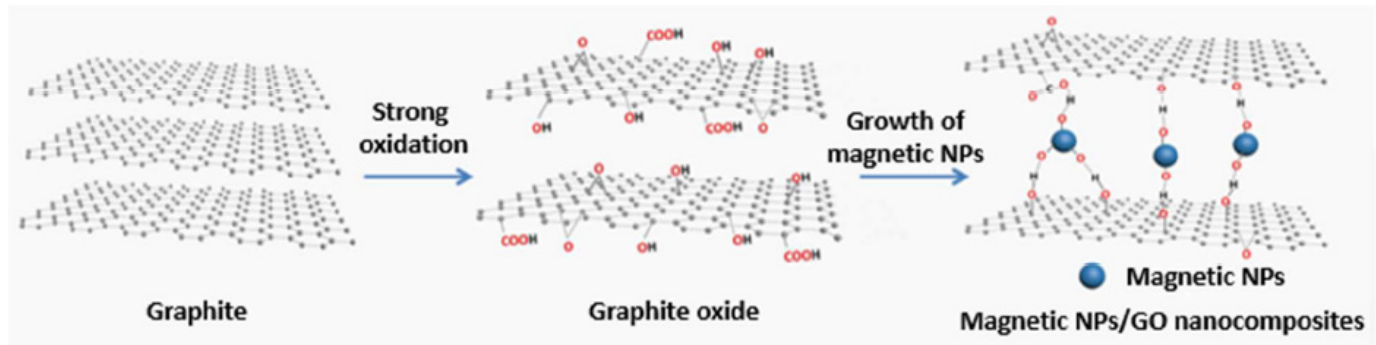

Figure 5. Hydrothermal synthesis of magnetic graphene oxide (mGO) via impregnation of $\mathrm{Fe}_{3} \mathrm{O}_{4}$ particles on the surface of GO flakes (Reproduced or adapted ref. [27], with permission from Royal Society of Chemistry).

Zhu et al. used $\mathrm{ZnSO}_{4} \cdot 7 \mathrm{H}_{2} \mathrm{O}$ to create $\mathrm{GO} /$ Brianyoungite $\mathrm{GO} / \mathrm{BY}$ ) composite with hollow spherical and flake-like morphologies. Wen et al. [29] incubated GO into a simulated body fluid for 7 days to ensure mineral growth, which resulted in GO-hydroxyapatite (GO-MWCNT-PDA) 3D flower-like composite. Khatamian et al. [23] fabricated $\mathrm{Fe}_{3} \mathrm{O}_{4} / \mathrm{GO} / \mathrm{Cu}$-ZEA via solid state dispersion of Cu-ZEA and $\mathrm{Fe}_{3} \mathrm{O}_{4}$ into GO suspension followed by sonication. Lingamdinne et al. [30] mixed Hydrazine hydrate, iron and nickel with GO and heated to $120^{\circ} \mathrm{C}$ to make rGO-Nickel Ferrite nanocomposite (rGO-NiFerrite NC).

\subsubsection{Hybrids with Chitosan and Cellulose}

Graphene-based hybrids have been widely used in the removal of heavy metals. Some of the materials used to make these composites include chitosan and cellulose. Cellulose is combined with GO to form Ethylenediaminetetraacetic acid (EDTA)-functionalized magnetic chitosan (CS) graphene oxide (GO) nanocomposites (EDTA-MCS/GO) through a reduction precipitation method [31]. This composite is characterized by FT-IR, XRD, SEM, MPMS, zeta-potential and BET analyses and is applicable for the removal of $\mathrm{Pb}^{2+}, \mathrm{Cu}^{2+}$, and $\mathrm{As}^{3+}$. Shahzad et al. synthesized EDTA-MCS/GO via 2-step process in which the first step yielded (MCS/GO), which was dried and mixed with $\mathrm{Na}_{2}$ EDTA to produce the composite [31]. Yang et al. [32] cross-linked GO and rGO with chitosan (CS) to create CS/GO and CS/RGO nanohybrids functionalized with amine and hydroxyl groups. Sun et al. prepared GO-chitosan composite decorated with ionic liquids as shown in Figure 6 [33].

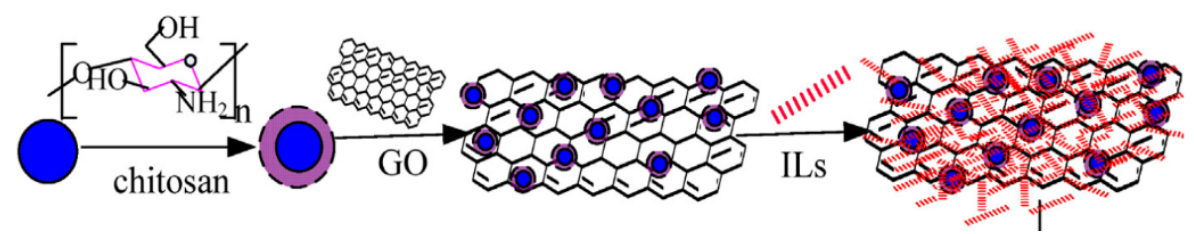

Figure 6. Synthesis route for preparation of GO-chitosan and GO-Chitosan-Ionic Liquid nanocomposites (Reproduced or adapted from ref. [33], with permission from Elsevier, 2020).

\subsubsection{Graphene Hybrids with Polymers}

Zhu et al. fabricated a magnetic composite by polymerizing $\mathrm{Fe}_{3} \mathrm{O}_{4}$ and adding it to graphene to develop polypyrrole-graphene (PPy-GO) nanocomposites [34]. Yang et al. polymerized Lignosulfonate and Polyaniline with GO via ultrasonication and vigorous mixing in HCL to produce (LS-GO-PANI) [35]. Tadjarodi et al. added 2-pyridinecarboxaldehyde thiosemicarbazone to GO to create (GO/2-PTSC) assisted with ultrasonic waves [36]. Sulfuric acid doped poly-diaminopyridine/graphene (G-PDAP) was synthesized by Dinda and Saha via the mutual oxidation-reduction technique by adding 2,6-Diamino pyridine to a GO suspension [37]. Najafabadi et al. used glyoxal as a crosslinking agent to develop chitosan/graphene oxide using electrospinning [38]. Li et al. cross-linked DTPA and mGO using diethylenetriamine to produce (DTPA/MGO) [39]. Zare-Dorabei et al. modified graphene oxide with 2,20-dipyridylamine to make (GO-DPA) for the simultaneous adsorption of different metal ions [40]. 
Nano sized hydrated manganese oxide was grown by Wan et al. [41] on GO to fabricate (HMO@GO), a nanocomposite with a high selectivity for lead. Fu et al. prepared magnetic $\mathrm{Fe}_{3} \mathrm{O}_{4}$-encapsulated poly $\left(\mathrm{C}_{3} \mathrm{~N}_{3} \mathrm{~S}_{3}\right)$ polymer/rGO nanocomposite following the method shown in Figure 7 [42].These are only some of the hybridizations mentioned in this review. Other composites will be discussed throughout the manuscript.

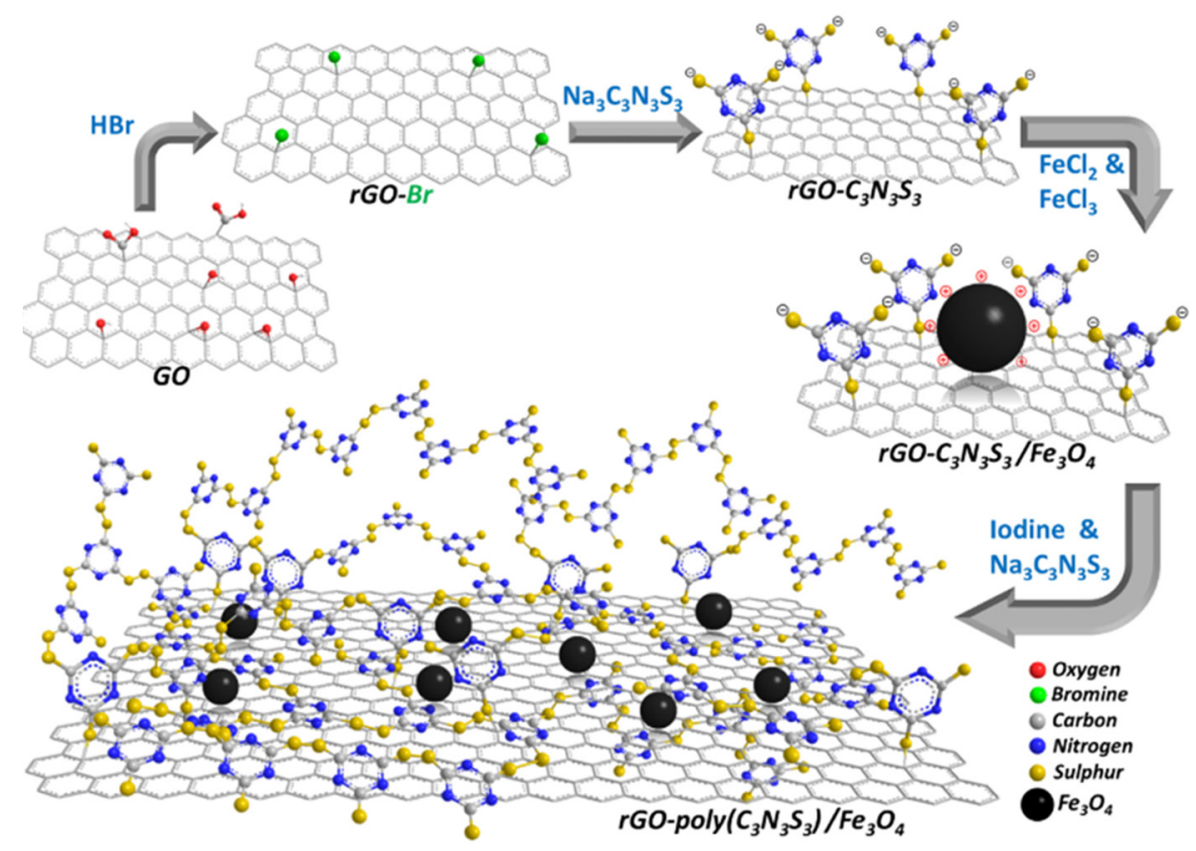

Figure 7. Schematic showing pathway for hybridization of GO with different compounds (Reproduced or adapted from ref. [42], with permission from Elsevier, 2020).

\section{Adsorption Measurements and Data Analysis}

Water solution containing various concentrations of heavy metal ions are used to carry out the adsorption studies typically at $\mathrm{pH} 5.5$ and room temperature. After equilibrium is achieved, the following parameters are measured or calculated: initial concentration $\left(C_{0}, \mathrm{mg} / \mathrm{L}\right)$, equilibrium concentration $\left(C_{e}, \mathrm{mg} / \mathrm{L}\right)$, maximum adsorption capacity $\left(Q_{e}, \mathrm{mg} / \mathrm{g}\right)$, adsorption percentage $(\%)$, the kinetics are studies by measuring the adsorption capacity at a given time $\mathrm{t}\left(Q_{t}, \mathrm{mg} / \mathrm{g}\right)$, solution volume $(\mathrm{V}, \mathrm{L})$, weight of $\mathrm{GO}(\mathrm{m}, \mathrm{g})$, and the final concentration of metal ions $\left(C_{f}, \mathrm{mg} / \mathrm{L}\right)$. The equations are based on the mass balance of the reaction, as follows:

$$
\begin{gathered}
Q_{e}=\frac{\left(C_{o}-C_{e}\right) V}{m} \\
Q_{t}=\frac{\left(C_{o}-C_{t}\right) V}{m} \\
\text { Removal \% }=\frac{\left(C_{o}-C_{f}\right)}{C_{o}} * 100
\end{gathered}
$$

\subsection{Adsorption Mechanism}

There are two main contributors to the adsorption process. These are electrostatic forces between the negatively charged surface of GO and the positively charged heavy metal ions which leads to ion exchange. Therefore, the adsorption affinity of ions onto GO and rGO surfaces strongly depends on the electronegativity, first stability constant, and standard reduction potential. An example of the order in which metal ions are adsorbed on GO and $\mathrm{rGO}$ is: $\mathrm{Pb}$ (II) $>\mathrm{Cu}$ (II) $>>\mathrm{Cd}$ (II) $>\mathrm{Zn}$ (II). 
The adsorption affinity is not dependent on the ionic radius of the heavy metals but more on their relative positions in the electro chemical series. However, the capacity can increase or decrease with temperature depending on heat of adsorption, i.e., exothermicity or endothermicity of the process [43].

\subsection{Adsorption Kinetics and Isotherms}

Studying the kinetics of the adsorption process is crucial not only to identify the adsorption mechanism but also to ensure the proper design of the adsorption process in terms of the required residence time. In general, experiments are designed to collect data on the change of the adsorbate concentration $\left(C_{t}\right)$ and adsorption capacity $\left(Q_{t}\right)$ versus adsorption time $(t)$ and various kinetic models are used to regress these data to find the kinetic model that best describes the collected data. For the adsorption of heavy metal ions on GO-based substances, two kinetic models are commonly applied, pseudo-1st-order kinetic model and pseudo-2nd-order kinetic model.

Adsorption isotherms are important as they express the dependence of adsorption capacities on the equilibrium concentration of adsorbent and adsorbate in the solution and provide information about the mechanism and the interaction between adsorbates and adsorbents. The isotherm models which are commonly used to describe the adsorption capacities and characteristics of heavy metals on different graphene materials are Freundlich, Langmuir, Redlich-Peterson, Sips, and Temkin models.

\subsection{Effects of Adsorption Conditions}

The main factors affecting the adsorption process are temperature, $\mathrm{pH}$, contact time, adsorbent dosage, and the metal ions initial concentration. Increasing the temperature increases the adsorption rate by diffusion but usually reduces the adsorption capacity. Increasing the adsorbent dosage leads to an increase in the adsorption rate and the percentage of metal ion removal but decreases the specific adsorption capacity. Moreover, an increase in the solid content may lead to "folding" of the GO thus denying access to active binding sites. The initial rate is always high and gradually decreases. Longer contact time ensures that equilibrium is reached and the maximum adsorption capacity at that specific conditions is obtained. The $\mathrm{pH}$ of the solution is very important as it can change the charge on the GO surface and the ion species in the solution. At relatively high $\mathrm{pH}(2<\mathrm{pH}<10)$, more functional groups are available and electrostatic interactions between the heavy metal ions and GO are stronger, but the optimum $\mathrm{pH}$ for maximum ion uptake may vary depending on the type of the heavy metal ion.

\section{Removal of Heavy Metals Using Graphene Materials}

\subsection{Arsenic Removal}

Table 2 shows the properties of various graphene-based adsorbents used for removal of arsenate, their adsorption properties and the applicable isotherm and kinetic models. The most utilized graphene-based material is their nanocomposites with metal oxides, inorganic, and organics molecules, with scattered performances with a slight skew towards metal oxide composites. These composites are mostly synthesized via hydrothermal treatment, solid state dispersion, aqueous thermal treatment, with the best performing composites are synthesized hydrothermally. 
Table 2. Adsorption properties of GO-based adsorbents used for removal of As (III) and As (V).

\begin{tabular}{|c|c|c|c|c|c|c|c|c|c|}
\hline Modification & Adsorbent & $\begin{array}{c}\text { Surface } \\
\text { Area } \\
\left(\mathrm{m}^{2} / \mathrm{g}\right)\end{array}$ & $\begin{array}{c}\text { G/As } \\
\text { Ratio } \\
\text { (g/g) }\end{array}$ & $\mathrm{pH}$ & $\begin{array}{l}\text { Max. As } \\
\text { Conc. } \\
\text { (mg/L) }\end{array}$ & $\begin{array}{c}\text { Capacity } \\
(\mathrm{mg} / \mathrm{g})\end{array}$ & $\begin{array}{c}\text { Max } \\
\text { Removal } \\
(\%)\end{array}$ & $\begin{array}{c}\text { Ads. } \\
\text { Isotherm }\end{array}$ & Ref. \\
\hline \multirow{4}{*}{ Organic } & GO & - & 16.6 & 7.6 & 20 & 74.1 & 100 & $\mathrm{~L}$ & [44] \\
\hline & Aminopyrazole-f-GO & - & 16.6 & 7.6 & 20 & 131.6 & 100 & $\mathrm{~L}$ & [44] \\
\hline & EDTA-MChitosn/GO & 450 & 66 & 7 & 5 & 42.8 & 80.4 & $\mathrm{~F}$ & [46] \\
\hline & Imino-Thiobiuret-rGO & - & 4 & 5 & 100 & 19 & 100 & $\mathrm{~L}$ & [47] \\
\hline \multirow[t]{3}{*}{ Metal Oxide } & $\mathrm{Fe}_{3} \mathrm{O}_{4} / \mathrm{RGO} / \mathrm{Cu}$ - Zeolite & 61.6 & - & 6 & 2000 & 50.5 & - & - & [23] \\
\hline & $\mathrm{Fe}_{3} \mathrm{O}_{4} / \mathrm{rGO}$ & 109 & 2 & 5.5 & 100 & 54.5 & 100 & $\mathrm{~L}$ & [50] \\
\hline & Magnetite-nonOxidG & 190 & 100 & 7.1 & 1 & 38 & - & $S$ & [51] \\
\hline \multirow[b]{2}{*}{ Inorganic } & $\mathrm{Ag}-\mathrm{Cu}_{2} \mathrm{O} / \mathrm{rGO}$ & - & 1000 & 7 & 2 & 11.5 & 83.9 & $\mathrm{~L}$ & [50] \\
\hline & LD-Hydroxide/GO & 35.4 & - & 5 & - & 183.1 & - & $\mathrm{L}$ & [52] \\
\hline
\end{tabular}

L: Langmuir, F: Freundlich, S: Sips.

GO modified with metal oxides and organic molecules are among the highest capacities, while inorganic composites ( $\mathrm{Mg}-\mathrm{Al}$ layered double hydroxides $\mathrm{GO}$ nanocomposite) when dispersed in water, it swells and forms viscous gel as shown in Figure 8 [52]. The high capacities in Table 2 demonstrate the excellent performance of the graphene-based materials very good capacities compared to the maximum reported capacity of other adsorbents including nanochitosan $(96.5 \mathrm{mg} / \mathrm{g})[54,55]$, amino-functionalized cellulose $(75.1 \mathrm{mg} / \mathrm{g})[56]$, and rice husk $(27.8 \mathrm{mg} / \mathrm{g})[57]$.

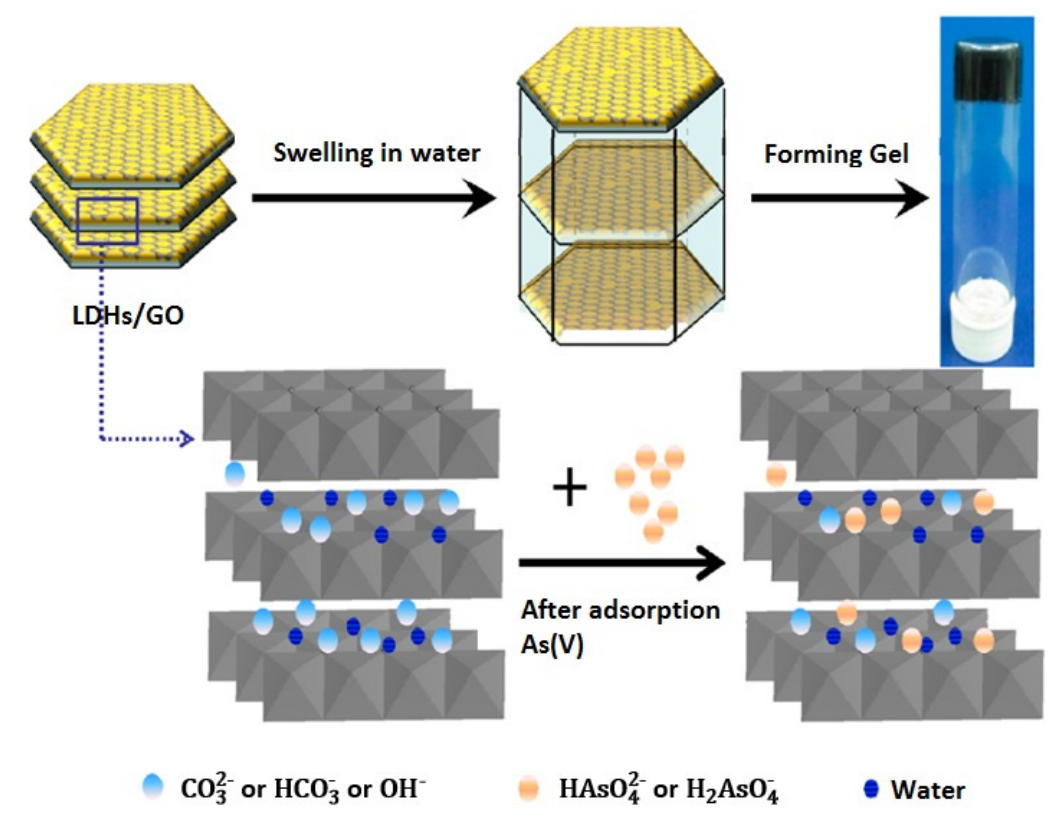

Figure 8. Mechanism for the adsorption mechanism of Arsenic on GO-LDH (Reproduced or adapted from ref. [52], with permission from American Chemical Society, 2020).

The kinetic of the arsenate adsorption on the various graphene materials provided in Table 2 follows with no exception pseudo second order kinetics, but the equilibrium adsorption results are best described by Langmuir isotherm with few exceptions where Sips and Freundlich models provided better fitting of the adsorption results for the cases of very low adsorbate concentration, e.g., $\mathrm{C}_{0} \sim 1 \mathrm{mg} / \mathrm{L}$.

An important and key aspect for the commercial application of the adsorption processes that are based on costly adsorbent, which is often neglected in research studies, is the regeneration and re-usability of the adsorbent. Few studies have investigated the regeneration and reuse of the graphene adsorbents using either a strong alkali $(\mathrm{NaOH})$ or strong acid $(\mathrm{HCl})$ in the desorption step. For As (III), 
M-nOG, EDTA-MCS/GO, and GO-f were found to be reusable. M-nOG was observed to retain 94.5\% of the first cycle capacity after 5 cycles [51]. Moreover, EDTA-MCS/GO depicted high levels of magnetic sensitivity in the presence of an external magnetic field after 4 cycles which indicated good reusability status [46]. On the other hand, GO-f's removal efficiency decreased by $11 \%$ after 3 cycles [44]. For As (V), M-nOG was found to be reusable and retained more than $92 \%$ of the first cycle capacity after 5 cycles [51].

\subsection{Lead Removal}

Because of the toxicity and abundance of lead in wastewater streams, there are large number of studies focused on the adsorption of $\mathrm{Pb}$ (II) on $\mathrm{GO}$ with several of studies investigating the regeneration of the graphene adsorbents. The properties of the graphene adsorbents and their lead (II) adsorption properties are summarized in Table 3. Graphene composites with inorganic materials represent the majority of the adsorbents used for Lead removal. Hybrids with $\mathrm{Fe}_{3} \mathrm{O}_{4}$ [41,48,58-61] was very popular choice due to its magnetic properties that allow separation of the adsorbent as shown in Figure 9 [62].

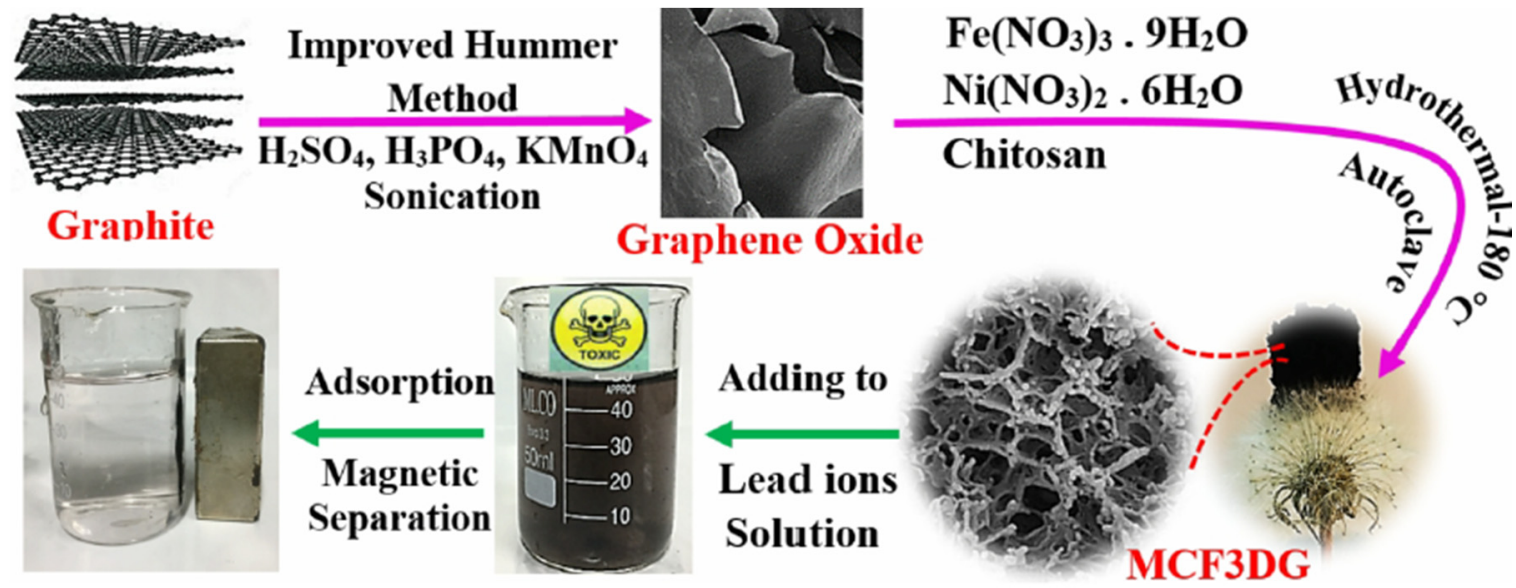

Figure 9. Synthesis of magnetic chitosan-functionalized 3D graphene nanocomposite MCF3DG (Reproduced or adapted from ref. [62], with permission from American Chemical Society, 2020).

The trends for the best synthesis method to yield a high capacity adsorbent were very hard to distinguish. The best capacities were achieved by modifying graphene with polymers and inorganics $[63,64]$. The majority of the composites were synthesized hydrothermally or with dispersion reaction. Solvothermal synthesis was used to composite inorganics with graphene [63]. Adsorbents based on combination of metal oxide and inorganics with graphene were synthesized via hydrothermal routes $[30,62,65,66]$. No strong correlation between the adsorbent surface area and the adsorption capacity of these composites can be made $[53,59,67]$.

The most economic synthesis methods are those using fewer chemicals and production steps. One-pot hydrothermal, dispersion and co-precipitation with few components would serve as a better synthesis option especially when coupled with good performance. For instance, 3D G/chitosan/nickel ferrite NC was synthesized hydrothermally in a few steps utilizing sustainable components like chitosan and is one of the best performing graphene-based adsorbents in the removal of lead from aqueous solutions with a maximum capacity of $957.3 \mathrm{mg} / \mathrm{g}$ [62].

The potential for the regeneration of the lead loaded adsorbents has also attracted much attention and several studies have investigated the reusability of the sorbents after regeneration. These include: $\mathrm{CoFe}_{2} \mathrm{O}_{4}-\mathrm{G}, \mathrm{NiFe}_{2} \mathrm{O}_{4}-\mathrm{G}, \mathrm{Fe}_{3} \mathrm{O}_{4}$-GS, EDTA-mGO, EDTA-MCS/GO, DTPA/MGO, GOMCS-IL, and IT-PRGO, Mg-Al LDH / pRGO [67-75]. Most of these nanocomposites were reusable with $\mathrm{Fe}_{3} \mathrm{O}_{4}-\mathrm{GS}$ and EDTA-mGO maintained more than $80 \%$ of their original adsorption capacity [76,77]. The best regeneration properties reported belong to $\mathrm{MGO}$-PAMAM, which retained the adsorption capacity after 5 cycles [70]. EDTA-MCS/GO depicted very high magnetic sensitivity in the presence of magnetic field 
after 4 cycles which indicates good reusability status [46]. The adsorption efficiency of DTPA/MGO was reduced by only $15.5 \%$ after 6 cycles signaling good reusability [39]. Similarly, GOMCS-IL suffered a slight loss in adsorption capacity after 4 cycles of adsorption-desorption, indicating good recyclability of GOMCS-IL [33]. IT-PRGO was also reusable and very efficient in adsorbing $\mathrm{Pb}$ (II) [47]. $\mathrm{Mg}-\mathrm{Al}$ $\mathrm{LDH} / \mathrm{pRGO}$ was effectively regenerated using $\mathrm{HCl}$ as an eluting agent and was reusable without loss in removal efficiency [26]. $\mathrm{NiFe}_{2} \mathrm{O}_{4}-\mathrm{G}$ and $\mathrm{CoFe}_{2} \mathrm{O}_{4}-\mathrm{G}$ had $98 \%$ and $100 \%$ desorbing capacity and the adsorption efficiency was almost retained during 3 repeated cycles $[64,66]$. Basic magnetized graphene oxides are also used to remove lead ions and showed maximum adsorption capacity of $326.7 \mathrm{mg} / \mathrm{g}$ [70]. It worth noting that the capacities for these graphene materials for lead vary not only with the material type and composition but also the conditions like $\mathrm{pH}$, surface area and lead concentrations as shown in Table 2.

Table 3. Adsorption properties of multiple GO-based adsorbents used in $\mathrm{Pb}$ (II) removal.

\begin{tabular}{|c|c|c|c|c|c|c|c|c|c|}
\hline Modification & Adsorbent & $\begin{array}{c}\text { Surface } \\
\text { Area } \\
\left(\mathrm{m}^{2} / \mathrm{g}\right)\end{array}$ & $\begin{array}{c}\mathrm{G} / \mathrm{Pb} \\
\text { Ratio } \\
(\mathrm{g} / \mathrm{g})\end{array}$ & $\mathrm{pH}$ & $\begin{array}{c}\text { Max. Pb } \\
\text { Conc. } \\
\text { (mg/L) }\end{array}$ & $\begin{array}{l}\text { Capacity } \\
(\mathrm{mg} / \mathrm{g})\end{array}$ & $\begin{array}{c}\text { Max. } \\
\text { Removal } \\
(\%)\end{array}$ & $\begin{array}{l}\text { Ads. } \\
\text { Isotherm }\end{array}$ & Ref. \\
\hline \multirow{9}{*}{$\mathrm{NO}$} & GO & - & 1.6 & - & 60 & 120 & 98 & - & [78] \\
\hline & Surface-Modified G & 101 & 4 & 5 & 1000 & 196 & - & $\mathrm{L}$ & [79] \\
\hline & $\mathrm{G}-\mathrm{Fe}$ & 201.3 & 1 & 6 & 100 & 645 & - & $\mathrm{L}$ & [80] \\
\hline & $\mathrm{TI} / \mathrm{GO} @ \mathrm{Fe}_{3} \mathrm{O}_{4}$ & 0.2 & 0.4 & 5 & 500 & 461 & - & $\mathrm{L}$ & [74] \\
\hline & SGO & - & - & - & - & 415 & - & $\mathrm{L}$ & [81] \\
\hline & ZIF-8@GO & 946.5 & - & 5 & 30 & 356 & 70 & $\mathrm{~L}$ & [82] \\
\hline & GO-SO $\mathrm{x} @ \mathrm{TiO}_{2}$ & 208 & - & - & - & 312 & - & $\mathrm{L}$ & [83] \\
\hline & $\mathrm{Fe}_{3} \mathrm{~S}_{4} / \mathrm{rGO}$ & 80.9 & 7.5 & 6 & 500 & 285.7 & 80 & $\mathrm{~L}$ & [84] \\
\hline & $\mathrm{GO}-\mathrm{SO}_{\mathrm{x}} \mathrm{R}$ & 102 & - & - & - & 285 & - & R-L & [83] \\
\hline \multirow{10}{*}{ Inorganic } & $\mathrm{GO}-\mathrm{SO}_{\mathrm{x}} \mathrm{R} @ \mathrm{SiO}_{2}$ & 92 & - & - & - & 172 & - & $\mathrm{L}$ & [83] \\
\hline & PG-C & 154.5 & - & 7 & 1 & 131.4 & 99.8 & $\mathrm{~L}$ & [85] \\
\hline & rGO-NiFerrite NC & 167.26 & 40 & 5 & 10 & 121.9 & 99 & $\mathrm{~L}$ & [30] \\
\hline & $\mathrm{Mg}-\mathrm{Al} \mathrm{LDH} / \mathrm{pRGO}$ & 79.4 & 0.2 & 4.5 & 100 & 116.2 & 100 & $\mathrm{~L}$ & [26] \\
\hline & pRGO & 50.2 & - & 4.5 & - & 65.0 & 100 & $\mathrm{~L}$ & [26] \\
\hline & CNF-C & 45.7 & - & 7 & 1.5 & 42.9 & 48 & $\mathrm{~L}$ & [85] \\
\hline & GO-OMS-20 & 872.9 & 1 & - & 100 & 39.5 & 78.7 & $\mathrm{~L}$ & [53] \\
\hline & $\mathrm{Cu}(\mathrm{tpa}) \cdot \mathrm{GO}$ & - & 0.29 & 7 & 35.1 & 37 & - & $\mathrm{L}$ & [86] \\
\hline & CdS-G / ZnS-G & - & 666.6 & 5.9 & 1.5 & 3.1 & 99 & $\mathrm{~L}$ & [87] \\
\hline & GONF & 136 & 0.75 & 5.5 & 1000 & 10.8 & 93 & $\mathrm{~L}$ & [88] \\
\hline \multirow{6}{*}{$\begin{array}{c}\text { Inorganic }+ \\
\text { Metal } \\
\text { Oxide }\end{array}$} & MCF3DG & - & 0.064 & 8.5 & 26 & 957.3 & 100 & $\mathrm{~L}$ & {$[62]$} \\
\hline & GO-W-MC & - & 0.03 & 7 & 300 & 253.2 & 89 & $\mathrm{~L}$ & {$[65]$} \\
\hline & MGL & 74.9 & 1.81 & 5 & 550 & 63.3 & 97.5 & $\mathrm{~L}$ & [66] \\
\hline & rGO-NiFerrite NC & 167.3 & 40 & 5 & 10 & 25.8 & $>99$ & $\mathrm{~L}$ & [30] \\
\hline & HMO@GO & 383.9 & - & 5 & - & 553.6 & 100 & $\mathrm{~F}$ & [41] \\
\hline & MNGH & 156 & 0.08 & 5 & 250 & 356.4 & - & $\mathrm{L}$ & {$[58]$} \\
\hline \multirow{7}{*}{$\begin{array}{l}\text { Metal } \\
\text { Oxide }\end{array}$} & GNPs/Fe-Mg-Cu & 104.9 & 120 & 7 & - & 251.3 & 99 & $\mathrm{~F}$ & [89] \\
\hline & GOMO & 623 & 5 & 6.5 & 80 & 190 & - & $\mathrm{L}$ & [59] \\
\hline & $\mathrm{CoFe}_{2} \mathrm{O}_{4}-\mathrm{G}$ & 126.36 & 8.3 & 5 & 30 & 142.8 & 100 & $\mathrm{~L}$ & {$[60]$} \\
\hline & $\mathrm{NiFe}_{2} \mathrm{O}_{4}-\mathrm{G}$ & 57.11 & 8.3 & 5 & 30 & 111.1 & 100 & $\mathrm{~L}$ & [60] \\
\hline & $\mathrm{G}-\mathrm{ZnO}$ & - & 100 & 6 & 10 & 23.4 & 92 & $\mathrm{~L}$ & [90] \\
\hline & L-Glu/GO & - & 0.6 & 5 & 2000 & 513.4 & - & $\mathrm{L}$ & [63] \\
\hline & Chitosan/GO & - & 0.5 & 3 & 1000 & 461.3 & - & $\mathrm{R}-\mathrm{P}$ & {$[38]$} \\
\hline \multirow{8}{*}{ Organic } & MWCNT-PDA/GO & 356.1 & 0.167 & 6 & 400 & 350.9 & - & $\mathrm{L}$ & [91] \\
\hline & $\begin{array}{l}\text { PAamidoamine-g } \\
\text { mGO }\end{array}$ & - & - & 6 & - & 326.7 & 92.6 & $\mathrm{~L}$ & {$[70]$} \\
\hline & DTC-GO & - & 5 & 5.3 & 50 & 132.0 & - & $\mathrm{L}$ & {$[92]$} \\
\hline & IT-PRGO & - & 0.08 & 5 & 400 & 101.5 & 98 & $\mathrm{~L}$ & [47] \\
\hline & GOMCS-IL & 357 & 5 & 5 & 200 & 85 & - & $\mathrm{L}$ & [33] \\
\hline & GO-TETA-DAC & 762 & - & 5 & 100 & 80.9 & 77 & $\mathrm{~L}$ & [67] \\
\hline & Pb-MCGO & 392.5 & - & 5 & - & 79 & 90 & $\mathrm{~L}$ & [93] \\
\hline & MCGO & 382.5 & - & 5 & - & 77 & - & $\mathrm{L}$ & [94] \\
\hline
\end{tabular}


Table 3. Cont

\begin{tabular}{|c|c|c|c|c|c|c|c|c|c|}
\hline Modification & Adsorbent & $\begin{array}{c}\text { Surface } \\
\text { Area } \\
\left(\mathrm{m}^{2} / \mathrm{g}\right)\end{array}$ & $\begin{array}{c}\mathrm{G} / \mathrm{Pb} \\
\text { Ratio } \\
\text { (g/g) }\end{array}$ & $\mathrm{pH}$ & $\begin{array}{c}\text { Max. Pb } \\
\text { Conc. } \\
\text { (mg/L) }\end{array}$ & $\begin{array}{c}\text { Capacity } \\
(\mathrm{mg} / \mathrm{g})\end{array}$ & $\begin{array}{c}\text { Max. } \\
\text { Removal } \\
(\%)\end{array}$ & $\begin{array}{c}\text { Ads. } \\
\text { Isotherm }\end{array}$ & Ref. \\
\hline \multirow{8}{*}{$\begin{array}{c}\text { Organic + } \\
\text { Metal } \\
\text { Oxide }\end{array}$} & EDTA-mGO & 49.9 & 0.5 & 4.1 & 100 & 268.4 & 95.5 & $\mathrm{~F} / \mathrm{T}$ & {$[76]$} \\
\hline & $\mathrm{GO} / \mathrm{Fe}_{3} \mathrm{O}_{4}-\mathrm{g}-\mathrm{G}$ & - & - & 5 & - & 181.4 & - & $\mathrm{L}$ & [95] \\
\hline & rGO-PDTC/ $/ \mathrm{Fe}_{3} \mathrm{O}_{4}$ & 194.8 & 0.25 & 6 & 100 & 147.1 & - & $\mathrm{L}$ & [68] \\
\hline & $\mathrm{RGO} / \mathrm{Fe}_{3} \mathrm{O}_{4}$ & 58 & - & 5.5 & 30 & 48 & 96 & $\mathrm{~L}$ & [61] \\
\hline & g-C-EN-GO & - & 0.08 & 7 & 3127 & 186.5 & 55.1 & $\mathrm{~L}$ & [96] \\
\hline & $\mathrm{GO}+\mathrm{Zn} @ \mathrm{NH}_{4} \mathrm{Cl}$ & - & 1 & - & 635 & 17900 & 99 & $\mathrm{~F}$ & [97] \\
\hline & RGO/PAM & - & 0.6 & 6 & 1500 & 1000 & - & $\mathrm{L}$ & {$[64]$} \\
\hline & GOCA & - & - & 5 & 200 & 602 & & $\mathrm{~L}$ & [98] \\
\hline \multirow{6}{*}{ Polymer } & EDA-RGO & 28 & 0.5 & 7 & 200 & 413.2 & - & $\mathrm{L}$ & [99] \\
\hline & DTPA/MGO & - & 0.025 & 3 & 400 & 387.6 & - & $\mathrm{L}$ & [39] \\
\hline & MMSP-GO & - & 5 & 9 & 20 & 333 & - & $\mathrm{L}$ & [100] \\
\hline & PAS-GO & 53.7 & 0.025 & 4.9 & 400 & 312.5 & 100 & $\mathrm{~L}$ & [101] \\
\hline & LS-GO-PANI & - & 0.4 & 5 & 1000 & 216.4 & 98.3 & $\mathrm{~L}$ & [35] \\
\hline & $\mathrm{GO} \mathrm{Fe}_{3} \mathrm{O}_{4}-\mathrm{DETA}$ & - & - & 5.5 & 0.11 & 172.4 & 100 & $\mathrm{~L}$ & [102] \\
\hline
\end{tabular}

L: Langmuir, F: Freundlich, T: Temkin, R-P: Redlich-Peterson.

Despite the large number of adsorption studies for the removal of lead (II) using graphene oxides and derivatives of graphene oxide, almost all the equilibrium adsorption results are best-modeled using the Langmuir isotherm. Most of the kinetic results follows pseudo-second order kinetics with exception of Mg-Al LDH/pRGO and pRGO, which followed Elovich kinetics model [26], HMO@GO that followed the Intraparticle Diffusion kinetics [41], and Chitosan/GO that followed the Double-exponential kinetic model [38]. Moreover, as shown in Table 2 the adsorption capacity of lead (II) on various graphene materials are exceptionally high and ranged between 150 and $1000 \mathrm{mg} / \mathrm{g}$, which are much higher than the capacity on other adsorbents including coconut-based activated carbon (83 mg/g) [103], activated Melocanna baccifera Roxburgh charcoals (bamboo) $(77 \mathrm{mg} / \mathrm{g}$ ) [104], chitosan (115 mg/g) [105], sphagnum peat moss (75 mg/g) [106], e-waste exchange resin and Lewatit (721 and $391 \mathrm{mg} / \mathrm{g}$ ) [107], and steel-making dust (209 mg/g) [108]. In one report, the measured capacity of Lead on GO+Zn@NH ${ }_{4} \mathrm{Cl}$ was $17,900 \mathrm{mg} / \mathrm{g}$ which is extremely high, although the conditions and results of the study may not be realistic [97].

\subsection{Cadmium Removal}

The adsorption capacity, removal efficiency, and the isotherm models for the adsorption of Cadmium (II) on different graphene materials are summarized in Table 4. The reported adsorption capacity ranged between 116 to $386 \mathrm{mg} / \mathrm{g}$ for high initial Cadmium (II) concentrations, the adsorption kinetics followed the pseudo-2nd order, and the adsorption thermodynamics is consistent with the Langmuir isotherm.

The most common routes used for synthesis of graphene composites used for Cadmium removal were the solvothermal, hydrothermal, dispersion, and co-precipitation methods. However, nanoscale zero-valent iron-reduced graphene oxide composite was prepared via plasma-reduction method and graphene oxide embedded calcium alginate was prepared via drop-wise formation method to create bead like structures [109]. The best performing adsorbent reported applied an inorganic modification to graphene oxide and so did the second best $[83,108]$. Nevertheless, these adsorbents required extensive processes to synthesize, not taking into consideration the steps required for basic GO. This may have a negative impact on the cost and could increase it dramatically especially when taking scale-up into consideration.

Regeneration and reusability of the graphene materials are examined by several groups and mGO- DTPA, G-NiFe $\mathrm{O}_{4}, \mathrm{G}-\mathrm{CoFe}_{2} \mathrm{O}_{4}$, GO-DPA, rGO-NZVI and GO-f are found to be reusable with a slight decrease in capacity with number of cycles. For example, the Cadmium adsorption capacities of DTPA/MGO-based composites synthesized following the route shown in Figure 10 decreased by 
only $10.3 \%$ after 6 cycles [39]. G-NiFe $\mathrm{O}_{4}$ and $\mathrm{G}-\mathrm{CoFe}_{2} \mathrm{O}_{4}$ retained $98 \%$ and $100 \%$ of their capacity during 3 repeated cycles [60]. GO-DPA also maintained more than $80 \%$ of its removal efficiency after 3 cycles [40]. rGO-NZVI did not show any significant decrease in efficiency after 4 cycles of adsorption and desorption [109]. The recyclability of GO-f after 3 cycles was comparable to those reported in literature with $89 \%$ of the maximum capacity achieved [44].

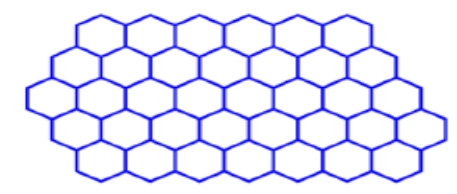

Graphene

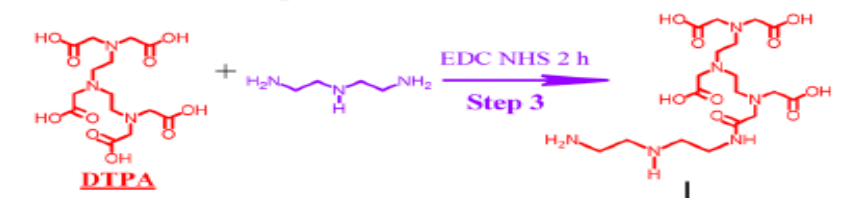

Step 1

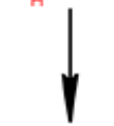

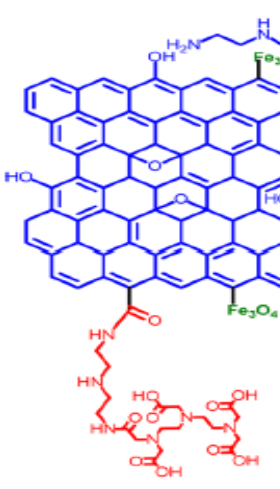
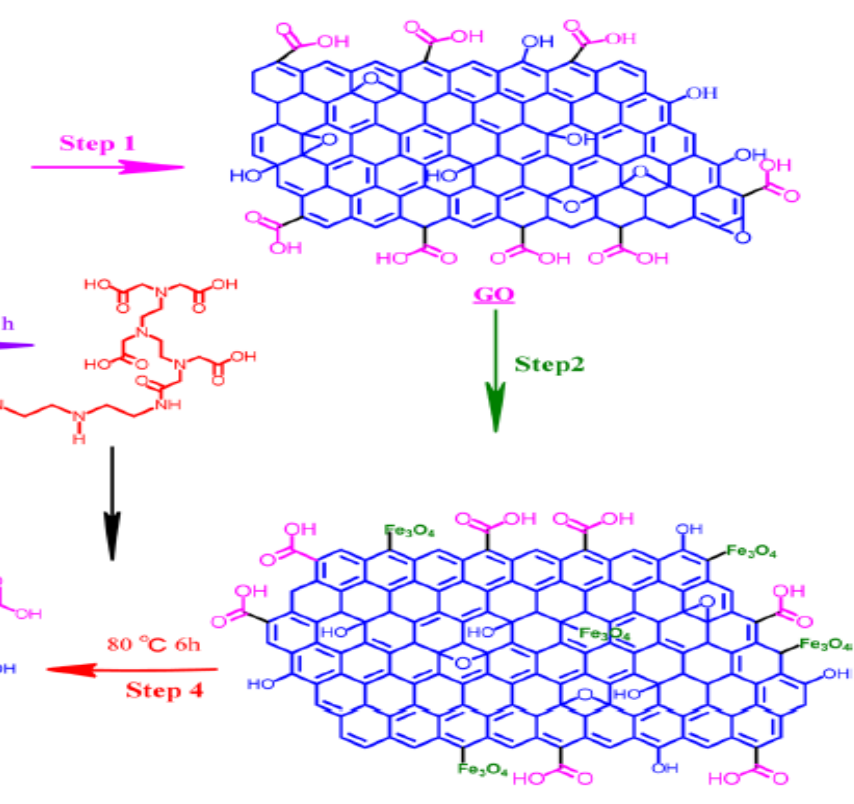

MGO

Figure 10. Synthesis Processes and Chemical Structure of DTPA/MGO (Reproduced or adapted from ref. [39], with permission from American Chemical Society, 2020).

Magnetized DTPA-mGO has been synthesized by combining $\mathrm{Fe}_{2} \mathrm{O}_{3}$, GO and DTPA forming a compound with a higher metal binding and electrostatic forces thus improving adsorption capacity [31].

Cadmium is another highly toxic heavy metal, where the kinetics of its adsorption with various conventional adsorbents including Amberlite IR-120 synthetic resin-101 mg/g [110], modified sugarcane bagasse pith-188 mg/g [111], hydroxyapatite-181 mg/g [112], modified magnetic chitosan-202 mg/g [113], magnetic dithiocarbamate- $83.21 \mathrm{mg} / \mathrm{g}$ [68], and e-waste derived alumino-silicate ion exchange resin-235 mg/g [114] are represented by the pseudo-second order model. In comparison, GO-based adsorbents had better results overall with capacities ranging from $3.6 \mathrm{mg} / \mathrm{g}$ to $426 \mathrm{mg} / \mathrm{g}$. In a highlight case, a huge capacity of $8.4 \mathrm{~g} / \mathrm{g}$ was reached where the adsorption process happened using the in-situ reduction of $\mathrm{GO}$ with $\mathrm{NH}_{4} \mathrm{Cl}$ and Zinc [97]. The entire list of GO-based adsorbents followed the pseudo second order kinetic model. 
Table 4. Adsorption properties of multiple GO-based adsorbents used in Cd (II) removal.

\begin{tabular}{|c|c|c|c|c|c|c|c|c|c|}
\hline Modification & Adsorbent & $\begin{array}{c}\text { Surface } \\
\text { Area } \\
\left(\mathrm{m}^{2} / \mathrm{g}\right)\end{array}$ & $\begin{array}{c}\text { G/Cd } \\
\text { Ratio } \\
(\mathrm{g} / \mathrm{g})\end{array}$ & $\mathrm{pH}$ & $\begin{array}{c}\text { Max } \\
\text { Cd Conc. } \\
\text { (mg/L) }\end{array}$ & $\begin{array}{l}\text { Capacity } \\
(\mathrm{mg} / \mathrm{g})\end{array}$ & $\begin{array}{c}\text { Max } \\
\text { Removal } \\
(\%)\end{array}$ & $\begin{array}{l}\text { Ads. } \\
\text { Isotherm }\end{array}$ & Ref. \\
\hline None & GO nanosheets & - & 5 & 6 & 100 & 167 & - & $\mathrm{L}$ & [115] \\
\hline \multirow{7}{*}{ Inorganic } & NZVI/rGOs & 117.9 & - & 5 & - & 425.7 & 100 & $\mathrm{~L}$ & [109] \\
\hline & GO-SOxR@TiO 2 & 208 & - & - & - & 384 & - & $\mathrm{F}$ & [83] \\
\hline & Surface modified G & 101 & 4 & $2-8$ & 1000 & 199.9 & - & $\mathrm{L}$ & [79] \\
\hline & $\mathrm{Cu}(\mathrm{tpa}) \cdot \mathrm{GO}$ & - & 0.3 & 7 & 35.9 & 53 & - & $\mathrm{L}$ & [86] \\
\hline & GO-OMS-20 & 872.9 & 1 & - & 100 & 48 & 96.9 & $\mathrm{~L}$ & {$[53]$} \\
\hline & nZVI/rGO & - & 12 & 6.5 & 50 & 46.5 & 82.4 & $\mathrm{~L}$ & [116] \\
\hline & CdS-G/ZnS-G & - & 1000 & 5.9 & 1 & 3.6 & 97 & $\mathrm{~L}$ & [87] \\
\hline \multirow{11}{*}{$\begin{array}{l}\text { Metal } \\
\text { Oxide }\end{array}$} & $\begin{array}{c}\mathrm{rGO} / \mathrm{magnetite} / \mathrm{Ag} \\
\text { NHs }\end{array}$ & - & 1.8 & 4 & 112.4 & 386.8 & 100 & $\mathrm{~L}$ & {$[22]$} \\
\hline & GO-MO & 383.9 & 0.02 & 6 & 500 & 202 & 99 & $\mathrm{~F}$ & [117] \\
\hline & aminoMGO & 189.9 & - & 7 & - & 184.7 & - & $\mathrm{L}$ & [118] \\
\hline & MMSP-GO & - & 5 & 9 & 20 & 167 & - & $\mathrm{L}$ & [100] \\
\hline & rGO-PDTC/ $\mathrm{Fe}_{3} \mathrm{O}_{4}$ & 194.8 & 0.3 & 6 & 100 & 116.3 & - & $\mathrm{L}$ & [68] \\
\hline & $\mathrm{CoFe}_{2} \mathrm{O}_{4}-\mathrm{G}$ & 126.4 & 0.8 & 7 & 30 & 105.3 & 80 & $\mathrm{~L}$ & [60] \\
\hline & mGO & 44.5 & 7 & 7 & - & 90.2 & - & $\mathrm{L}$ & [69] \\
\hline & $\mathrm{NiFe}_{2} \mathrm{O}_{4}-\mathrm{G}$ & 57.1 & 0.5 & 7 & 50 & 74.6 & 50 & $\mathrm{~L}$ & [60] \\
\hline & $\mathrm{GOFe}_{3} \mathrm{O}_{4}$-DETA & - & - & 5.5 & 0.12 & 59.9 & 99.7 & $\mathrm{~L}$ & [102] \\
\hline & $\mathrm{GO}$ & - & 0.01 & 6 & 1000 & 23.9 & - & $\mathrm{F}$ & [119] \\
\hline & DTPA/MGO & - & 0.03 & 3 & 300 & 286.5 & - & $\mathrm{L}$ & [39] \\
\hline \multirow{4}{*}{ Organic } & GO-f & - & 16.7 & 8.8 & 20 & 285.7 & 100 & $\mathrm{~L}$ & [44] \\
\hline & GO-DPA & - & 0.4 & 5 & 100 & 257.2 & 85 & $\mathrm{~L}$ & [40] \\
\hline & PNGF & - & 0.3 & - & 100 & 254.9 & 70 & - & [120] \\
\hline & GOCA & - & - & 5 & 200 & 181 & - & $\mathrm{L}$ & [98] \\
\hline
\end{tabular}

L: Langmuir, F: Freundlich.

\subsection{Nickel Removal}

The adsorption properties of $\mathrm{Ni}$ (II) on graphene-based materials are presented in Table 5. Although there are fewer reported studies on nickel than most of the other heavy metals, the trends are very similar to the previous heavy metal studies. All the kinetic studies follow the pseudo-second order out of the five literature studies, four equilibrium models use the Langmuir isotherm, while one model, with a very low initial nickel (II), ion concentration of $5 \mathrm{mg} / \mathrm{L}$, reports a Freundlich isotherm fit. The adsorption of nickel (II) is enhanced at $\mathrm{pH} 2.0-5.5$ owing to the electrostatic force between the negatively charged graphene oxide and positively charged Nickel (II) ions [121]. At pH higher than 7.5, electrostatic repulsion occurs between the negatively charged $\mathrm{Ni}(\mathrm{II})$ and $\mathrm{GO}$, which is why adsorption is greatly decreased at $\mathrm{pH}$ higher than 7.5 [121]. The highest adsorption capacity is $344 \mathrm{mg} / \mathrm{g}$ with $\mathrm{GO}_{-} \mathrm{SO}_{\mathrm{x}} \mathrm{R} @ \mathrm{TiO}_{2}$ [71]. The adsorption capacity results for the removal of nickel from water show a dependence on the surface area. There is only a limited number of papers reporting nickel removal by GO derivatives. The regeneration of adsorbent is critical issue, yet only GO-DPA synthesized as described in Figure 11 has been tested for number of adsorption regeneration cycles and $>80 \%$ of the adsorption efficiency was retained after 3 cycles proving its potential reusability [40]. 


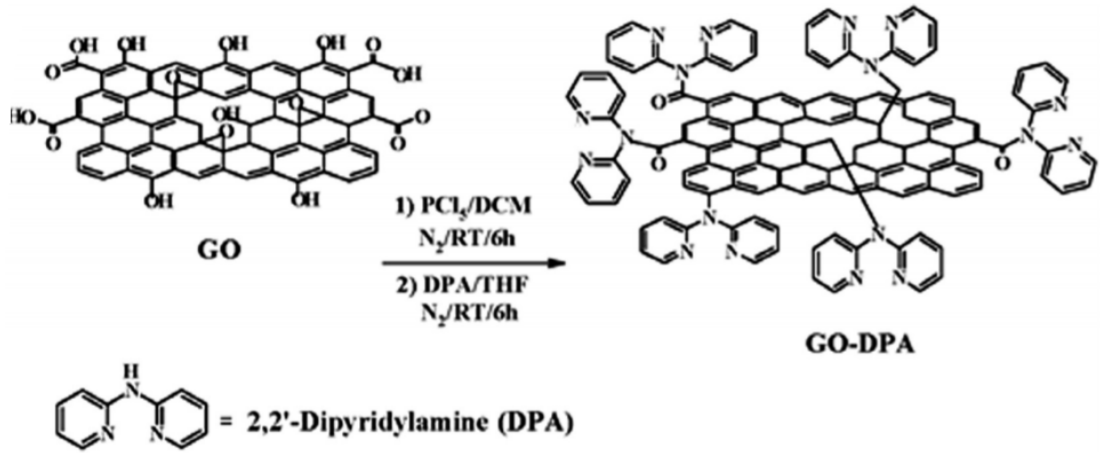

Figure 11. Synthesis Processes and Chemical Structure of GO-DPA (Reproduced or adapted from ref. [40], with permission from Royal Society of Chemistry, 2020).

The synthesis process of 2, 20-dipyridylamine (DPA) was a simple precipitation in the presence of nitrogen gas. Dry dichloromethane and phosphorous pentachloride were added to GO and mixed to yield a highly sensitive and stable composite for the adsorption of nickel [122].

Table 5. Adsorption properties of multiple GO-based adsorbents used in Ni (II) removal.

\begin{tabular}{|c|c|c|c|c|c|c|c|c|c|}
\hline Modification & Adsorbent & $\begin{array}{c}\text { Surface } \\
\text { Area } \\
(\mathrm{m} 2 / \mathrm{g})\end{array}$ & $\begin{array}{l}\text { G/Ni } \\
\text { Ratio } \\
\text { (g/g) }\end{array}$ & $\mathrm{pH}$ & $\begin{array}{c}\text { Max } \\
\text { Ni Conc. } \\
\text { (mg/L) }\end{array}$ & $\begin{array}{l}\text { Capacity } \\
\text { (mg/g) }\end{array}$ & $\begin{array}{c}\text { Max } \\
\text { Removal } \\
(\%)\end{array}$ & $\begin{array}{c}\text { Ads. } \\
\text { Isotherm }\end{array}$ & Ref. \\
\hline I & GO-SO $\mathrm{R}_{\mathrm{X}} @ \mathrm{TiO}_{2}$ & 208 & - & - & - & 344 & - & R-P & [91] \\
\hline $\mathrm{O}$ & GO-DPA & - & 0.4 & 5 & 100 & 180.9 & $>85$ & $\mathrm{~L}$ & [40] \\
\hline $\mathrm{O}$ & $\begin{array}{c}\mathrm{GO}+\mathrm{P} . \\
\text { Cateniannulatus }\end{array}$ & 185.6 & 0.833 & 4 & 60 & 104.2 & 95 & L & [121] \\
\hline $\mathrm{MO}$ & $\mathrm{Fe}_{3} \mathrm{O}_{4} / \mathrm{rGO}$ & 109 & 3.91 & 5.5 & 51.1 & 76.3 & 100 & $\mathrm{~L}$ & [123] \\
\hline- & GO & - & - & 4 & 25 & 35.6 & - & $\mathrm{L}$ & [124] \\
\hline MO & $\mathrm{Fe}_{3} \mathrm{O}_{4}$-GS & 62.4 & 2 & 7 & 5 & 22.1 & 86 & $\mathrm{~F}$ & [77] \\
\hline
\end{tabular}

I: Inorganic, O: Organic, MO: Metal Oxide L: Langmuir, F: Freundlich, R-P: Redlich-Peterson.

The reported capacities of 76, 104, $181 \mathrm{mg} \mathrm{Ni}$ (II)/g GO are linked to the high initial adsorbate concentrations of 51, 60, $100 \mathrm{mg} / \mathrm{L}$, respectively [116]. These values compare favorably with reported values for other adsorbents but are not as high as certain ion exchangers. The nickel adsorption properties on conventional adsorbents include silica-immobilized biomass (4.1 mg/g) [125], histidine modified chitosan beads- $56 \mathrm{mg} / \mathrm{g}$ [126], protonated rice bran - $102 \mathrm{mg} / \mathrm{g}$ [127], pine cone biochar-115 mg/g [128].

\subsection{Mercury Removal}

The results of studies on the adsorption characteristics of $\mathrm{Hg}$ (II) ions on GO (s) are presented in Table 6. The Table shows that all the kinetic studies were pseudo-2nd order model. Most equilibriums follow the Langmuir isotherm except for five Freundlich systems; however, three of the Freundlich isotherms were for studies performed at very low mercury ion concentrations so the equilibrium saturation level is reached. The other two Freundlich isotherms were applicable for GO-complexes, so possibly more than one adsorption mechanism is involved. The best performing graphene composites for mercury removal were modified with organic compounds. The five highest capacities reported all utilizes organic compounds in preparation of the adsorbents [36,44,47,76,129,130].

All studies were on batch experiments. The most common synthesis methods were hydrothermal, solvothermal, and diffusion methods. Some adsorbents were fabricated through a mechanical route whether ultra-sonication [35], electrospinning [50], or drop-wise formation [98]. There was no evident relation between surface area and maximum capacity.

High adsorption capacities of mercury in the range of $168-700 \mathrm{mg} / \mathrm{g}$ have been obtained with different graphene composites [34,36,47,129-134]. 
Table 6. Adsorption properties of multiple GO-based adsorbents used in $\mathrm{Hg}$ (II) removal.

\begin{tabular}{|c|c|c|c|c|c|c|c|c|c|}
\hline Modification & Adsorbent & $\begin{array}{c}\text { Surface } \\
\text { Area } \\
\left(\mathrm{m}^{2} / \mathrm{g}\right)\end{array}$ & $\begin{array}{l}\text { G/Hg } \\
\text { Ratio } \\
\text { (g/g) }\end{array}$ & $\mathrm{pH}$ & $\begin{array}{c}\text { Max } \\
\text { Hg Conc. } \\
\text { (mg/L) }\end{array}$ & $\begin{array}{l}\text { Capacity } \\
\text { (mg/g) }\end{array}$ & $\begin{array}{c}\text { Max } \\
\text { Removal } \\
(\%)\end{array}$ & $\begin{array}{l}\text { Ads. } \\
\text { Isotherm }\end{array}$ & Ref. \\
\hline \multirow{4}{*}{ Polymer } & Magnetic PPy-GO & 1737.6 & 0.9 & 7 & 100 & 400 & 99 & $\mathrm{~L}$ & [35] \\
\hline & GOCA & - & 2 & 5 & 50 & 374 & 97 & $\mathrm{~L}$ & [98] \\
\hline & $\mathrm{Fe}_{3} \mathrm{O}_{4}$-GS & 62.4 & 2 & 7 & 5 & 23.0 & 93 & $\mathrm{~F}$ & [77] \\
\hline & $\mathrm{Ag} /$ graphene & 251 & 1 & 5 & 100 & 91.7 & 98.8 & $\mathrm{~F}$ & [129] \\
\hline \multirow[t]{3}{*}{ Inorganic } & GO-OMS-20 & 872.9 & 1 & - & 100 & 49 & 98.5 & $\mathrm{~L}$ & [53] \\
\hline & $\mathrm{GO} / \mathrm{Fe}-\mathrm{Mn}$ & 153.4 & 12 & 7 & 5 & 32.9 & 89 & $\mathrm{~S}$ & [130] \\
\hline & GMA-1 & - & - & - & - & 719 & - & - & [135] \\
\hline \multirow{6}{*}{$\begin{array}{l}\text { Organic + } \\
\text { Inorganic }\end{array}$} & Cellulose-GNC & 14.9 & 12 & 6 & 50 & 410 & 77 & $\mathrm{~F}$ & [136] \\
\hline & GCS & 157 & - & 6 & 0.89 & 299.4 & 80 & $\mathrm{~F}$ & [50] \\
\hline & $\mathrm{SGO} / \mathrm{Fe}-\mathrm{Mn}$ & - & 0.5 & 6 & 100 & 233.4 & 95.6 & BET & [132] \\
\hline & IT-PRGO & - & 0.4 & 5 & 900 & 624 & 96 & $\mathrm{~L}$ & [47] \\
\hline & GO/2-PTSC with US & - & 0.3 & 5 & 90 & 555 & $>85$ & $\mathrm{~L}$ & [36] \\
\hline & EDTA-mGO & 49.9 & 1.2 & 4.1 & 100 & 508.4 & 94.9 & $\mathrm{~F} / \mathrm{T}$ & [76] \\
\hline \multirow[t]{5}{*}{ Organic } & $\begin{array}{l}\text { Phytic acid induced } \\
\text { GO }\end{array}$ & - & - & 7.2 & - & 361 & 97 & $\mathrm{~L}$ & [133] \\
\hline & SeCA-GH & - & 0.9 & 3 & 100 & 331 & 99 & $\mathrm{~L}$ & [137] \\
\hline & GO-f & - & 16.6 & 8.3 & 20 & 227.3 & 100 & $\mathrm{~L}$ & [44] \\
\hline & rGO-PDTC/Fe ${ }_{3} \mathrm{O}_{4}$ & 194.8 & 0.3 & 6 & - & 158.7 & - & $\mathrm{L}$ & [68] \\
\hline & HT-rGO-N & 386 & 0.2 & 5 & 11 & 63.8 & 98 & $\mathrm{~F}$ & [138] \\
\hline
\end{tabular}

L: Langmuir, F: Freundlich, T: Temkin, S: Sips, BET: Brunauer-Emmett-Teller.

The $\mathrm{Hg}$ (II) capacities on conventional adsorbents are frequently much lower with adsorption capacities ranging from single digit values to over $200 \mathrm{mg} / \mathrm{g}$. Other reported capacities on conventional adsorbents include walnut shell derived activated carbon-151 mg/g [139].

Utilization of the magnetic properties of $\mathrm{Fe}_{3} \mathrm{O}_{4}$ to facilitate the decontamination process by simplifying the separation process described in Figure 12.

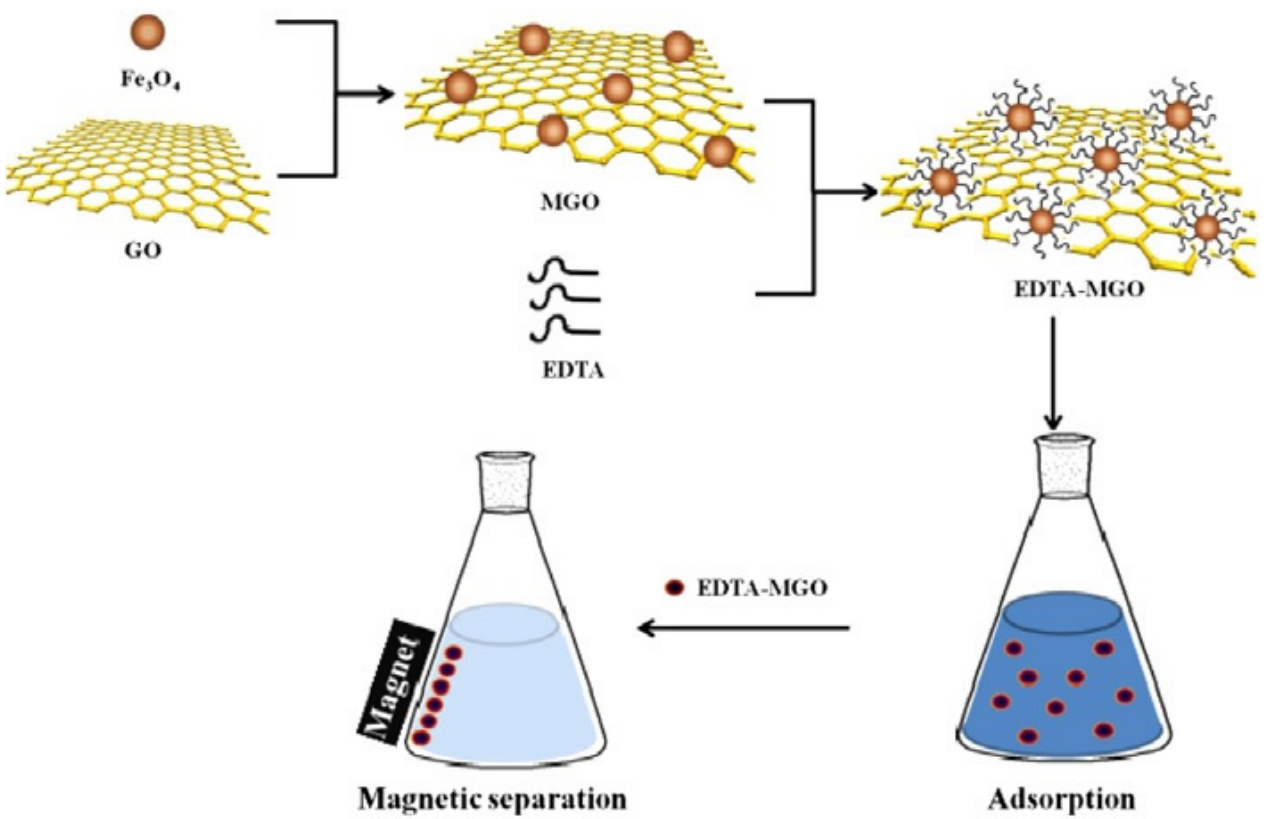

Figure 12. Adsorption and separation process of mercury on EDTA-MGO (Reproduced or adapted from ref. [76], with permission from Elsevier, 2020).

Composite adsorbents have higher adsorption capacities than pure graphene oxide. A novel adsorbent was designed by chemically modifying graphene oxide (GO) with 2-pyridinecarboxaldehyde thiosemicarbazone (2-PTSC) as ligand for removing $\mathrm{Hg}$ (II) from aqueous solutions with capacity 
reaching $555 \mathrm{mg} / \mathrm{g}$. During this experiment the effect of $\mathrm{pH}$, mercury concentrations and time on adsorption capacity were investigated. Moreover, EDTA-mGO, Ag/graphene, GO/2-PTSC, GO/2-PTSC with US, GO-f were identified as reusable adsorbents. Almost half of the studies investigated the regeneration of the adsorbents. Some studies reported excellent regeneration after 6 cycles but had lower maximum capacities in comparison to the rest of the adsorbents $[129,137]$. Reusability studies on $\mathrm{Ag} / \mathrm{graphene}$ indicated that the removal efficiency was more than $95 \%$ after 6 cycles [129]. Studies on EDTA-mGO showed that removal capacity remained at $85.9 \%$ after five cycles showing best recycling properties amongst all [76]. GO/2-PTSC and GO/2-PTSC with US were found to have similar desorption results to all reusable adsorbents in literature with $87 \%$ after 3 cycles [36]. Finally, the adsorption efficiency of GO-f was found to only decrease $21 \%$ after five cycles [44].

\subsection{Chromium Removal}

The adsorption capacities of $\mathrm{Cr}$ (III) and $\mathrm{Cr}$ (VI) on various GO-based adsorbents are presented in Table 7. The equilibrium adsorption results for most of the graphene adsorbents followed the Langmuir model with a few exceptions that followed Freundlich model and were attributed to a low initial chromium solution concentration or the fact that $\mathrm{Fe}_{3} \mathrm{O}_{4}$ was a component additive and the resulting adsorbent material had more than one active surface adsorption site. On the other hand, the kinetic data are well represented by the pseudo-2nd order model with two exceptions where the double-exponential and intraparticle diffusion models were followed [140].

The double exponential kinetic model assumes the adsorption reaction occurs in two steps comprising a fast stage step 1 and a slow stage step 2, with first order rate constants, $k_{A}$ and $k_{B}$, for each step respectively. This model is represented by Equation (4):

$$
q_{t}=q_{e}-\left(d_{A} / m\right) \exp \left(-k_{A} t\right)-\left(d_{B} / m\right) \exp \left(-k_{B} t\right)
$$

where $q_{t}$-amount of chromium adsorbed at time $\mathrm{t}, q_{e}$-amount of chromium adsorbed at equilibrium e. $d_{A}$ and $d_{B}$-amounts of rapidly and slowly adsorbed fraction of chromium (mg/L), respectively, $m$-mass of adsorbent.

G-PDAP is a sulfuric acid doped diaminopyridine polymer prepared in-situ on the surface of GO through mutual oxidation-reduction process as detailed in Figure 13. At the first step, graphene oxide is prepared from graphite through modified Hummer's method like in most cases and diaminopyridine is then added in the presence of $\mathrm{H}_{2} \mathrm{SO}_{4}$ which introduces more active sites on the surface of the adsorbents [37].

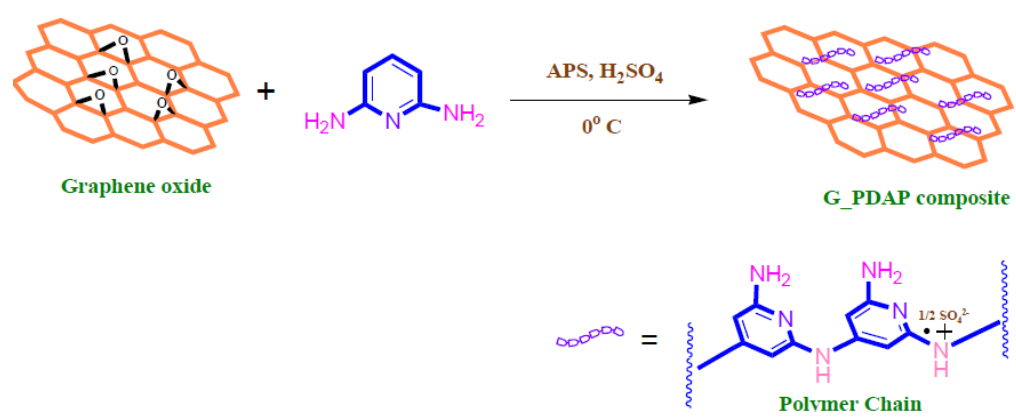

Figure 13. Synthesis process of G-PDAP composite (Reproduced or adapted from ref. [37], with permission from Elsevier, 2020).

Ultrasonication was a popular synthesis route with organic graphene composites with competitive results $[38,80,141]$. Nevertheless, the most common synthesis route is hydrothermal. Polymer/graphene composites showed the best performance. Surface areas of the adsorbents were not always reported in the studies, yet when comparing the results, no relation was detected with capacity. 
Table 7. Adsorption properties of different GO-based adsorbents used in removal of Cr (IV) removal.

\begin{tabular}{|c|c|c|c|c|c|c|c|c|c|}
\hline Modification & Adsorbent & $\begin{array}{l}\text { Surface } \\
\text { Area } \\
\left(\mathrm{m}^{2} / \mathrm{g}\right)\end{array}$ & $\begin{array}{l}\text { G/Cr } \\
\text { Ratio } \\
\text { (g/g) }\end{array}$ & $\mathrm{pH}$ & $\begin{array}{c}\text { Max } \\
\text { Cr Conc. } \\
\text { (mg/L) }\end{array}$ & $\begin{array}{l}\text { Capacity } \\
(\mathrm{mg} / \mathrm{g})\end{array}$ & $\begin{array}{c}\text { Max } \\
\text { Removal } \\
(\%)\end{array}$ & $\begin{array}{c}\text { Ads. } \\
\text { Isotherm }\end{array}$ & Ref. \\
\hline \multirow{5}{*}{ Inorganic } & rGO-NiFerrite NC & 167.3 & 40 & 4 & 10 & 126.6 & 99 & $\mathrm{~L}$ & [142] \\
\hline & $\mathrm{G}-\mathrm{Fe}-\mathrm{Pb}$ & 201.3 & 0.5 & 6 & 22 & 100 & 100 & $\mathrm{~L}$ & [80] \\
\hline & PG-C & 154.5 & - & 6 & 0.5 & 68.9 & 100 & $\mathrm{~L}$ & [85] \\
\hline & GO-OMS-20 & 872.9 & 1 & - & 100 & 45.5 & 96 & $\mathrm{~L}$ & [53] \\
\hline & GONF & 136 & 0.5 & 5.5 & 1000 & 9.3 & 99.6 & $\mathrm{~L}$ & [88] \\
\hline \multirow{5}{*}{$\begin{array}{l}\text { Metal } \\
\text { Oxide }\end{array}$} & $\mathrm{GOF} / \mathrm{Fe}_{3} \mathrm{O}_{4}$ & 574.2 & 2.5 & 2 & 200 & 258.6 & 99.97 & F & [143] \\
\hline & $\mathrm{G}-\mathrm{ZnO}$ & - & 100 & 6 & 10 & 46.3 & 90 & $\mathrm{~L}$ & [90] \\
\hline & $\mathrm{NPG} / \mathrm{Fe}_{3} \mathrm{O}_{4}$ & 850 & 0.9 & 3 & 1000 & 43.5 & 80 & $\mathrm{~F}$ & [144] \\
\hline & HR-M-GO/Fe ${ }_{3} \mathrm{O}_{4}$ & 182 & 1.6 & 7 & 300 & 31.8 & 100 & $\mathrm{~L}$ & [145] \\
\hline & MGC & 97 & 0.03 & 6.6 & 60 & 5.5 & - & $\mathrm{L}$ & [146] \\
\hline \multirow{4}{*}{$\begin{array}{c}\text { Metal } \\
\text { Oxide + } \\
\text { Organic }\end{array}$} & $\mathrm{f}-\mathrm{Fe}_{3} \mathrm{O}_{4} / \mathrm{G}$ & 60 & 0.07 & $3-4$ & 600 & 280.6 & - & $\mathrm{L}$ & [147] \\
\hline & GCF & 74.4 & 10 & 2 & 50 & 270.3 & 96 & $\mathrm{~L}$ & [72] \\
\hline & $\mathrm{CoFe}_{2} \mathrm{O}_{4}$-TETA-GO & - & 4.4 & 2 & 100 & 180.1 & - & $\mathrm{L}$ & [148] \\
\hline & MCGO-IL & - & 5 & 3 & 200 & 145.4 & - & $\mathrm{L}$ & [149] \\
\hline \multirow{8}{*}{ Organic } & DAP-RGO & 46.7 & 2 & 1 & 500 & 393.7 & 96 & $\mathrm{~F}$ & [150] \\
\hline & Chitosan/GO & - & 0.5 & 6 & 1000 & 310.4 & $>90$ & R-P & [38] \\
\hline & $\mathrm{Cs} / \mathrm{CDTA}-\mathrm{GO}$ & - & - & 3.5 & 25 & 167.0 & 90 & $\mathrm{~L}$ & [31] \\
\hline & GEC & - & 8 & 2 & 50 & 86.2 & 92.5 & $\mathrm{~F}$ & [141] \\
\hline & GOSB & - & 0.03 & 3 & 100 & 76.9 & - & $\mathrm{L}$ & [151] \\
\hline & GAD & 37.6 & 0.001 & 4 & 200 & 72.7 & - & $\mathrm{L}$ & [152] \\
\hline & IT-PRGO & - & 4 & 5 & 250 & 63 & 96 & $\mathrm{~L}$ & [47] \\
\hline & MGNC & 42.1 & 3000 & 2 & 1 & 1.0 & 100 & - & [153] \\
\hline \multirow{6}{*}{ Polymer } & G-PDAP & 327.8 & 4 & 1 & 500 & 609.8 & 100 & $\mathrm{~L}$ & [37] \\
\hline & $\mathrm{PmPD} / \mathrm{rGO} / \mathrm{NFO}$ & - & 0.4 & 3 & - & 502.5 & - & $\mathrm{L}$ & [154] \\
\hline & GO-PEI & 1.2 & - & - & - & 436.2 & - & $\mathrm{L}$ & [155] \\
\hline & P(TA-TEPA)-PAM-RGO & - & - & 6 & - & 387.5 & - & $\mathrm{L}$ & [156] \\
\hline & $\mathrm{Fe}_{3} \mathrm{O}_{4}-\mathrm{GS}$ & 62.4 & 2.6 & 7.5 & 3 & 17.3 & 95 & $\mathrm{~F}$ & [77] \\
\hline & $\mathrm{Fe}_{3} \mathrm{O}_{4} / \mathrm{SiO}_{2}$-GO-PEI & - & 1 & 6 & 4 & 0.3 & - & $\mathrm{L}$ & [140] \\
\hline
\end{tabular}

L: Langmuir, F: Freundlich, R-P: Redlich-Peterson.

All these high capacities have the initial adsorbate concentration greater than $200 \mathrm{mg} / \mathrm{L}$. The ability to regenerate and reuse the GO-based adsorbents has been reported. In a few cases, $\mathrm{Fe}_{3} \mathrm{O}_{4} / \mathrm{SiO} 2-\mathrm{GO}-\mathrm{PEI}$ was recycled several times without a significant decrease in its adsorption capacity [140]. GONF was reusable effectively for 4 cycles for the adsorption of $\mathrm{Cr}$ (III) [88] and rGO-NiFerrite NC could be easily reused and recycled for 4 cycles [30]. The most cycles of regeneration done was reported on GCF to achieve $90 \%$ of the capacity after 10 iterations. This shows the superior stability of GCF over the other adsorbents [72,149].

GEC's adsorption capacity decreased slightly from $92.5 \%$ to $87.5 \%$ after 7 cycles, indicating it is suitable adsorbent for $\mathrm{Cr}$ (VI) removal [141]. For chitosan/GO, more than $90 \%$ of the total adsorption uptake in the first cycle is retained after the $5^{\text {th }}$ cycle of $\mathrm{Cr}$ (VI) removal [38]. Moreover, MCGO-IL retained $78 \%$ of the initial adsorption capacity after 5 cycles of $\mathrm{Cr}$ (VI) [148]. DAP-RGO was also recycled for five cycles and the maximum removal efficiency was reduced from $96 \%$ in the first cycle to $84 \%$ after the 5 th cycle, indicating the good reusability [150]. The regeneration studies for PG-C and CNF-C revealed that the adsorbents had the potential to be reused for multiple cycles in the adsorption of $\mathrm{Cr}$ (VI) [85]. Upon analysis of regeneration studies and maximum capacities achieved, G-PDAP is recommended as a cost-effective adsorbent for the removal of chromium from aqueous solutions [37].

\subsection{Copper Removal}

Removal of copper ions or copper complexes from water are most widely studied among all other metal ions due to its extensive occurrence especially in the microelectronics industry effluents. Table 8 summarizes the results for the adsorption of $\mathrm{Cu}$ (II) onto GO and GO composites. Similar to the case of other metal ions, the isotherm results of $\mathrm{Cu}$ removal using graphene materials are mostly well described by the Langmuir isotherm, but with several exceptions where Tempkin or 
Freundlich isotherms provide the best fit for the equilibrium data. The results that follow the multilayer heterogeneous adsorption isotherms may be attributed to the tendency of the copper ions to adsorb by complexation with oxygen lone pair electrons on different oxygenated functional groups present on the surfaces of the adsorbents. On the other hand, the kinetic data are well described by the pseudo- $2^{\text {nd }}$ order model. Only one study followed the Double Exponential kinetic model [38].

The highest copper uptake capacities shown in Table 7 are for A-Mgo (301 mg/g), $\beta$-CD/GPTMS/GO $352.7 \mathrm{mg} / \mathrm{g}$, FA-mGO $283.29 \mathrm{mg} / \mathrm{g}$, EDTA-MCS/GO (207.26 mg/g) [46], Chitosan/GO (423.8 mg/g), $\mathrm{Cu}$ (tpa).GO (235 mg/g), graphene oxide encapsulated polyvinyl alcohol/sodium alginate hydrogel microspheres (247.61 mg/g) <80\%, GCAM10 (457.5 mg/g) and mGO (353.59 mg/g). Other graphene-based materials used for the removal of copper ions showed lower capacity including crumpled graphene balls (22.56 mg/g), Magnetic dithiocarbamate/rGO (113.64 mg/g), $\beta$-Cyclodextrin conjugated graphene oxide $(117.07 \mathrm{mg} / \mathrm{g})$, and dialdehyde cellulose grafted graphene oxide composite $(65.1 \mathrm{mg} / \mathrm{g})$.

In addition to high adsorption capacity, it is important for the expensive GO derived adsorbents to have the ability to be regenerated and reused many times, whilst retaining a high capacity. In this regard EDTA-mGO, FA-mGO, EDTA-MCS/GO, DTPA/MGO, GO-DPA, chitosan/GO, GO-CTPy, $\mathrm{Fe}_{3} \mathrm{O}_{4}$, $\mathrm{Fe}_{3} \mathrm{O}_{4} / \mathrm{TiO} 2$, CS-IIP and $\mathrm{Fe}_{3} \mathrm{O}_{4} / \mathrm{HAP} / \mathrm{GQD}$ were found to be reusable. EDTA-mGO retained a 97.6\% removal efficiency after five cycles [83] and FA-mGO held $86.5 \%$ removal efficiency after six cycles, indicating that it is an efficient and economic adsorbent that can be easily retrieved and recycled due to it magnetic properties as shown in Figure 14 [134].

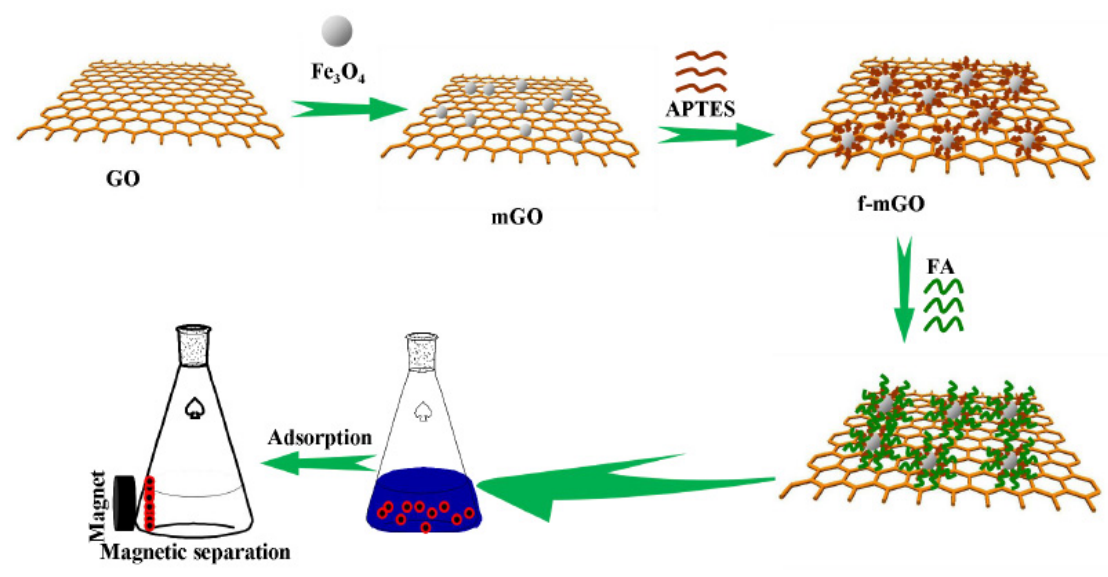

Figure 14. Synthesis, adsorption, and separation process of f-mGO (Reproduced or adapted from ref. [134], with permission from Elsevier, 2020).

Magnetic graphene oxide is prepared through the Impregnation Method $\left(\mathrm{mGO}_{\mathrm{i}}\right)$, simple emulsion and Co-precipitation $\left(\mathrm{mGO}_{\mathrm{p}}\right)[21,50,61,71,134]$. After synthesis, the adsorbent is characterized using various methods (SEM, FTIR, XRD, DTA, DTG, VSM) with results that show many possible interactions with the surface of this composite and its ability to remove copper [71].

Various methods were used to fabricate or synthesize the graphene composites used for the removal of copper. The three most common were solvothermal, hydrothermal and dispersion methods. In some cases, a combination of the methods was used to synthesize different components of the adsorbents [68,70]. The most common additive to graphene was organic, showing the most promise with regards to maximum capacities. Amino-MGO [118] reported the highest maximum capacity, although upon further analysis Chitosan/GO [38] is the recommended graphene composite for the removal of copper. It showed the best overall performance with regards to removal efficiency, regeneration properties, and adsorbent to adsorbate ratio. Furthermore, given that chitosan and graphene are abundant and not expensive compared to the other composites, it is the economical choice too. 
EDTA-MCS/GO showed high magnetic sensitivity in the presence of an external magnetic field after 4 cycles, which indicated good reusability status [46]. DTPA/MGO's total adsorption capacity for $\mathrm{Cu}$ (II) decreased by only $8.2 \%$ after 6 cycles [39]. The removal efficiency of GO-DPA reduced with the number of cycles but was still above $80 \%$ after 3 cycles, indicating reasonably good reusability [40]. More than $90 \%$ of the total adsorption in the first cycle takes place in the $5^{\text {th }}$ cycle for metal ions [38]. The adsorption capacity of GO-CTPy was still high enough after seven cycles to indicate that it has good reusability performance [157]. It also had the best regeneration properties of all studied graphene composites for copper removal. The decline of adsorption capacities in $\mathrm{Fe}_{3} \mathrm{O}_{4}$ and FTG were 9\% and $7.4 \%$ after 5 cycles [50]. CS-IIP's adsorption capacity decreased slightly after 5 cycles, showing that CS-IIP has good stability and could be used repeatedly [86].

The adsorption capacities for copper using the more conventional adsorbents are generally much lower than the high values reported in Table 7. For example the adsorption capacity for chitosan $(85 \mathrm{mg} / \mathrm{g})$ [73], DTPA-chitosan/alginate composite beads $(107 \mathrm{mg} / \mathrm{g})$ [32], iminodiacetate ion exchanger (145 mg/g) [158], mixed adsorbents (238 mg/g) [159], poly-dopamine coated natural zeolite (28 mg/g) all with lower capacities than the $300+\mathrm{mg} / \mathrm{g}$ capacity of the majority of graphene-based adsorbents shown in Table 7. The exception is the "superadsorbent" PAMAM CNT-dendrimers with a super-capacity of $3333 \mathrm{mg} / \mathrm{g}$ [160].

Table 8. Adsorption properties of different GO-based adsorbents used in $\mathrm{Cu}$ (II) removal.

\begin{tabular}{|c|c|c|c|c|c|c|c|c|c|}
\hline Modification & Adsorbent & $\begin{array}{c}\text { Surface } \\
\text { Area } \\
\left(\mathrm{m}^{2} / \mathrm{g}\right)\end{array}$ & $\begin{array}{c}\text { G/Cu } \\
\text { Ratio } \\
\text { (g/g) }\end{array}$ & $\mathrm{pH}$ & $\begin{array}{c}\text { Max Cu } \\
\text { Conc. } \\
\text { (mg/L) }\end{array}$ & $\begin{array}{l}\text { Capacity } \\
(\mathrm{mg} / \mathrm{g})\end{array}$ & $\begin{array}{c}\text { Max. } \\
\text { Removal } \\
(\%)\end{array}$ & $\begin{array}{l}\text { Adsorption } \\
\text { Isotherm }\end{array}$ & Ref. \\
\hline \multirow{6}{*}{ Inorganic } & $\mathrm{GO}-\mathrm{COOH}$ & 39.8 & 0.159 & $6-7$ & 700 & 357.1 & 99.4 & $\mathrm{~L}$ & [161] \\
\hline & BY-GO & 34.2 & 0.674 & 5 & 493.3 & 349.5 & - & $\mathrm{L}$ & [162] \\
\hline & $\mathrm{Cu}(\mathrm{tpa}) \cdot \mathrm{GO}$ & - & 0.04 & 7 & 228.1 & 235 & - & $\mathrm{L}$ & [86] \\
\hline & Graphene balls & - & - & 3.5 & 249.7 & 224.6 & 99 & $\mathrm{~F}$ & [163] \\
\hline & $\mathrm{ZnO}$ NR-rGO & - & 5 & 8 & 98.6 & 67.4 & 100 & $\mathrm{~L}$ & [164] \\
\hline & GO-MO & 383.9 & 0.02 & 6 & 500 & 240 & 99 & $\mathrm{~F}$ & [117] \\
\hline Metal & FTG & 422.8 & - & - & - & 87.4 & 72.1 & $\mathrm{~L}$ & [165] \\
\hline \multirow[t]{8}{*}{ Oxide } & SMGO & 92.8 & 8.35 & 4.7 & 73.7 & 62.7 & - & $\mathrm{L}$ & [166] \\
\hline & $\mathrm{G}-\mathrm{ZnO}$ & - & 100 & 6 & 10 & 37.5 & 96.56 & $\mathrm{~L}$ & [90] \\
\hline & GCAM10 & - & 0.4 & 4.9 & 500 & 457.5 & $>85$ & $\mathrm{~F}$ & [167] \\
\hline & Chitosan/GO & - & 0.5 & 6 & 1000 & 423.8 & $>90$ & $\mathrm{R}-\mathrm{P}$ & [38] \\
\hline & GO-DPA & - & 0.4 & 5 & 100 & 358.8 & $>85$ & $\mathrm{~L}$ & {$[40]$} \\
\hline & $\beta-\mathrm{CD} / \mathrm{GPTMS} / \mathrm{GO}$ & - & 1.25 & 7 & 200 & 352.7 & - & $\mathrm{L}$ & [168] \\
\hline & MWCNT-PDA & 356.1 & 0.167 & 6 & 400 & 318.5 & - & $\mathrm{L}$ & [91] \\
\hline & SA/PVA/GO & - & - & 8 & - & 247.7 & $>80$ & $\mathrm{~L}$ & [159] \\
\hline \multirow[t]{8}{*}{ Organic } & EDTA-MCS/GO & 49.9 & 6.6 & 7 & 50 & 207.3 & 86.8 & $\mathrm{~L}$ & [46] \\
\hline & $\mathrm{CS} / \mathrm{GO}_{10}$ & - & 0.1 & 5 & 100 & 202.5 & - & $\mathrm{F}$ & [32] \\
\hline & GAD & 37.6 & 0.01 & 4 & 200 & 169.5 & - & $\mathrm{L}$ & [152] \\
\hline & GO-CTPy & 57.3 & 16.7 & 6 & 90 & 119.6 & - & $\mathrm{L}$ & [157] \\
\hline & GOSB & - & 0.3 & 3 & 100 & 111.11 & - & $\mathrm{L}$ & [151] \\
\hline & GO-TETA-DAC & 445 & - & 5 & - & 65.1 & 77 & $\mathrm{~L}$ & [67] \\
\hline & IT-PRGO & - & 4 & 5 & 150 & 37 & 100 & $\mathrm{~L}$ & [47] \\
\hline & amino-MGO & - & - & 5.5 & - & 578.1 & - & $\mathrm{L}$ & [118] \\
\hline \multirow{3}{*}{$\begin{array}{c}\text { Organic + } \\
\text { Metal } \\
\text { Oxide }\end{array}$} & EDTA-mGO & 49.9 & 1 & 4.1 & 100 & 301.2 & 95.7 & $\mathrm{~T}$ & [76] \\
\hline & FA-mGO & - & 2 & 5 & 2000 & 283.3 & 96.8 & $\mathrm{~T}$ & [134] \\
\hline & Fe3O4@GO & 169.7 & 0.05 & 5 & 1000 & 32.5 & - & $\mathrm{F}$ & [169] \\
\hline \multirow{3}{*}{$\mathrm{O}+\mathrm{P}$} & rGO-PDTC/ $/ \mathrm{Fe}_{3} \mathrm{O}_{4}$ & 194.8 & 0.33 & 5 & - & 113.6 & - & $\mathrm{L}$ & [68] \\
\hline & g-C-EN-GO & & 0.26 & 7 & 959.2 & 46.4 & 43.1 & $\mathrm{~L}$ & [96] \\
\hline & mGO/PAMAM2.0 & - & - & 7 & 30 & 353.6 & 99.9 & $\mathrm{~F}$ & {$[70]$} \\
\hline \multirow{3}{*}{ Polymer } & DTPA/MGO & - & 0.033 & 3 & 300 & 131.4 & - & $\mathrm{L}$ & [39] \\
\hline & EDA-RGO & 28 & 0.5 & 7 & 200 & 55.3 & - & $\mathrm{L}$ & [99] \\
\hline & $\mathrm{MGO} / \beta-\mathrm{CD}$ & - & 1.4 & 5.5 & 100 & 30.98 & - & $\mathrm{F}$ & [170] \\
\hline \multirow{3}{*}{$\mathrm{P}+\mathrm{MO}$} & $\mathrm{GO} / \mathrm{Fe}_{3} \mathrm{O}_{4} / \mathrm{PEI}$ & 323.5 & 1 & 5 & 1000 & 157 & 97.1 & $\mathrm{~L}$ & [171] \\
\hline & MCGON & 132.9 & 0.167 & 7 & 100 & 217.4 & - & $\mathrm{L}$ & [172] \\
\hline & $\mathrm{CS} / \mathrm{GO} / \mathrm{Fe}_{3} \mathrm{O}_{4}$-IIP & - & 0.6 & 6 & 500 & 132 & - & $\mathrm{F}$ & [46] \\
\hline
\end{tabular}

L: Langmuir, F: Freundlich, R-P: Redlich-Peterson, T: Temkin, MO: Metal Oxide, P: Polymer, O: Organic. 


\subsection{Other Metals}

Table 9 summarized the adsorption capacity, kinetics and experimental conditions for the adsorption of several important and toxic metals using GO and GO-based composites. All studies followed the pseudo second order kinetic model except PAA-MGA in the removal of selenium, which followed Intra-Particle Diffusion model [81]. These metals include radioactive materials. U, Th, Sc, $\mathrm{Nd}$; catalytic materials such as $\mathrm{Pd}, \mathrm{Pt}$; emerging materials in waste streams including Se and $\mathrm{Mn}$. For the adsorption of U (VI), GO-BSA showed good regeneration efficiency showing the potential for reusability [173]. Additionally, $\mathrm{rGO} / \mathrm{LDH}^{\prime}$ s adsorption capacity remained at $97.2 \%$ after three cycles [174]. While GO has high reusability, as its desorption percentages reached 95.45\% for Au(III), 94.64\% for Pd (II) and 99.37\% for Pt(IV) [175]. MGO's adsorption values can be compared to those for adsorbents that have been reported before, suggesting that it could be reusable [176]. The desorption percentage of $\mathrm{CSGO}_{5}$ remained about $95 \%$ with both $\mathrm{Au}(\mathrm{III})$ and $\mathrm{Pd}(\mathrm{II})$ after 3 cycles, showing that it is possible to successfully reuse $\mathrm{CSGO}_{5}$ for the adsorption of both metals [177].

Table 9. Adsorption properties of different GO-based adsorbents used for removal of various metals.

\begin{tabular}{|c|c|c|c|c|c|c|c|c|c|}
\hline Metal & Adsorbent & $\begin{array}{c}\text { Surface } \\
\text { Area } \\
\left(\mathrm{m}^{2} / \mathrm{g}\right)\end{array}$ & $\begin{array}{c}\text { Adsorbent/ } \\
\text { Adsorbate } \\
\text { (g/g) }\end{array}$ & $\mathrm{pH}$ & $\begin{array}{c}\text { Max. } \\
\text { Adsorbate } \\
\text { Conc. } \\
\text { (mg/L) }\end{array}$ & $\begin{array}{c}\text { Capacity } \\
(\mathrm{mg} / \mathrm{g})\end{array}$ & $\begin{array}{c}\text { Max. } \\
\text { Removal } \\
(\%)\end{array}$ & $\begin{array}{c}\text { Ads. } \\
\text { Isotherm }\end{array}$ & Ref. \\
\hline $\mathrm{Ag}$ (III) & TEOA-GO-PC & - & 0.02 & - & 1000 & 850 & - & $\mathrm{L}$ & [175] \\
\hline Ag (III) & CNTs/GO & - & 0.167 & 5.9 & - & 534.8 & 86.42 & $\mathrm{~L}$ & [77] \\
\hline $\mathrm{Au}(\mathrm{III})$ & $\mathrm{CSGO}_{5}$ & 4.2 & 0.4 & 4 & 500 & 1077 & - & $\mathrm{L}$ & [133] \\
\hline $\mathrm{Au}$ (III) & $\mathrm{GO}$ & - & 0.033 & 6 & 90 & 108.3 & - & $\mathrm{L}$ & [133] \\
\hline $\mathrm{Ca}(\mathrm{II})$ & pAMPS-g-GT & - & 0.3 & 7 & 1000 & 114.2 & 53.45 & $\mathrm{~L}$ & [178] \\
\hline Co (II) & $\mathrm{GO}$ & 2.8 & 0.01 & 5.5 & 1000 & 21.3 & 93 & $\mathrm{~F}$ & [159] \\
\hline Co (II) & $\mathrm{M}-\mathrm{GO}$ & - & 40 & 6.5 & 50 & 17.1 & 100 & $\mathrm{~L}$ & [176] \\
\hline Co (II) & zero-valent FeNP-G & - & 0.67 & 5.7 & 600 & 134.3 & 90 & $\mathrm{~F}$ & [109] \\
\hline Co (II) & $\mathrm{GO}$ & - & 10 & 5 & 10 & 43.6 & - & $\mathrm{S}$ & [179] \\
\hline Co (II) & $\mathrm{ZnO}$ NR-rGO & - & 5 & 8 & 90.1 & 36.4 & 10 & $\mathrm{~L}$ & [164] \\
\hline Co (II) & TRG & 10 & 2 & 6 & 700 & 733 & 90 & $\mathrm{~L}$ & [81] \\
\hline $\mathrm{Fe}(\mathrm{II})$ & MGO & - & 0.36 & 5.5 & 84 & 43.2 & 100 & $\mathrm{~F}$ & [176] \\
\hline $\mathrm{Fe}$ (III) & $\mathrm{Cu}(\mathrm{tpa}) . \mathrm{GO}$ & - & 0.14 & 7 & 73.7 & 78 & - & $\mathrm{L}$ & [86] \\
\hline $\mathrm{Fe}(\mathrm{III})$ & GO-PAMAM 2.0 & - & - & - & - & 29.7 & - & - & [39] \\
\hline $\mathrm{Fe}$ (III) & $\mathrm{GO}$ & 330.7 & 0.6 & - & 20 & 133.3 & 90.5 & $\mathrm{~L}$ & [180] \\
\hline $\mathrm{Fe}(\mathrm{III})$ & GO & - & - & 4 & 25 & 27.3 & - & $\mathrm{L}$ & [71] \\
\hline Gd (III) & $\mathrm{CNT} / \mathrm{GO}$ & - & 4 & 5.9 & 12 & 427.7 & - & $\mathrm{L}$ & [181] \\
\hline Mn (II) & $\mathrm{Cu}(\mathrm{tpa}) . \mathrm{GO}$ & - & 0.09 & 7 & 112.4 & 150 & - & $\mathrm{L}$ & [86] \\
\hline Mn (II) & MGO & - & 0.364 & 5.5 & 82.5 & 16.5 & 100 & $\mathrm{~F}$ & [176] \\
\hline Mn (II) & EDA-RGO & 28 & 0.5 & 7 & 200 & 42.5 & - & $\mathrm{L}$ & [99] \\
\hline Nd (III) & GO-C 4 & 372 & - & 7 & - & 232.6 & - & $\mathrm{F}$ & [135] \\
\hline Nd (III) & $\mathrm{GO}-\mathrm{C}_{6}$ & 518 & - & 7 & - & 220 & - & $\mathrm{F}$ & [135] \\
\hline Nd (III) & $\mathrm{GO}-\mathrm{C}_{8}$ & 62.4 & - & 7 & - & 312 & - & $\mathrm{F}$ & [135] \\
\hline Pd (II) & $\mathrm{CSGO}_{5}$ & 4.2 & 2 & 3 & 100 & 216.9 & - & $\mathrm{L}$ & [133] \\
\hline Pd (II) & GO & - & 0.06 & 6 & 50 & 80.8 & - & $\mathrm{L}$ & [133] \\
\hline $\mathrm{Pt}(\mathrm{IV})$ & GO & - & 0.06 & 6 & 50 & 71.4 & - & $\mathrm{L}$ & [133] \\
\hline $\operatorname{Re}(\mathrm{VII})$ & $\mathrm{ZrO}_{2} @ \mathrm{rGO}$ & 272.73 & - & 4 & - & 43.6 & - & $\mathrm{L}$ & [88] \\
\hline Se (IV) & PAA-MGO & - & 0.38 & 5.8 & 4 & 120.1 & 99.3 & $\mathrm{~F}$ & [42] \\
\hline Se (IV) & PAA-MGO & - & - & 3.1 & 0.4 & 156 & 99.3 & $\mathrm{~F}$ & [81] \\
\hline Se (VI) & PAA-MGO & - & 0.38 & 5.8 & 4 & 83.7 & 99.7 & $\mathrm{~F}$ & [159] \\
\hline $\mathrm{Sr}(\mathrm{II})$ & GO-Hap ZEA & 91.9 & 10 & 7 & 300 & 702.2 & 95 & $\mathrm{~L}$ & [29] \\
\hline Th (IV) & a-GOM2 & 2001 & 0.25 & 3.8 & 1000 & 408.8 & - & $\mathrm{L}$ & [98] \\
\hline $\mathrm{U}(\mathrm{VI})$ & GO-BSA & - & - & 6 & 200 & 389 & 98 & $\mathrm{~L}$ & [72] \\
\hline $\mathrm{U}(\mathrm{VI})$ & a-GOM2 & 2001 & 0.5 & 3.8 & 1000 & 66.8 & - & $\mathrm{L}$ & [98] \\
\hline $\mathrm{U}(\mathrm{VI})$ & PA-GO & - & 6.25 & 5.5 & 80 & 124.3 & - & $\mathrm{L}$ & [182] \\
\hline $\mathrm{U}(\mathrm{VI})$ & $\mathrm{rGO} / \mathrm{LDH}$ & 256.8 & 3.84 & 4 & 130 & 277.8 & 99 & $\mathrm{~L}$ & [72] \\
\hline $\mathrm{Zn}(\mathrm{II})$ & GO & - & 1.67 & 5 & 40 & 246 & 99.3 & $\mathrm{~L}$ & [183] \\
\hline Zn (II) & GO & - & - & 6 & 2439.1 & - & 94 & $\mathrm{~L}$ & [184] \\
\hline Zn (II) & $\mathrm{GOSO}_{\mathrm{x}} \mathrm{R} @ \mathrm{TiO}_{2}$ & 208 & - & - & - & 285 & - & R-L & [83] \\
\hline Zn (II) & $\mathrm{GO}$ & - & 14.9 & 6.2 & 0.5 & 243 & 93.1 & $\mathrm{~L}$ & [185] \\
\hline Zn (II) & $\mathrm{Cu}(\mathrm{tpa}) \cdot \mathrm{GO}$ & - & 0.11 & 7 & 91.7 & 89 & - & $\mathrm{F}$ & [86] \\
\hline Zn (II) & GO-PANI & - & 0.5 & 7 & 100 & - & 84.8 & $\mathrm{~L}$ & [184] \\
\hline Zn (II) & GO-PAMAM 2.0 & - & - & - & - & 64.6 & - & - & [39] \\
\hline
\end{tabular}




\section{Conclusions}

GO provides an economically viable and efficient method to treat wastewater containing harmful heavy metals. Various methods are available for synthesizing composite GO materials providing materials that are tailored for removal of specific species. The carboxyl, hydroxyl, and epoxy functional oxygen groups on GO facilitate the adsorption of ions by providing active binding sites. This review analyzes the metal adsorption results from over one hundred and eighty recent studies using GO and GO-derived materials for the removal of more than 10 metal ions. The adsorption capacities of different metals are analyzed and compared with the capacity of conventional adsorbents. In almost every case, the metal adsorption capacity using GO materials are considerably higher. Although the production of GOs is expensive at present, these high capacities may lead to lower cost for treatment of wastewater streams polluted with metal ions as not only is the required adsorbent amount lower, but also the size of adsorption equipment will be less and hence the plant capital cost will be less. There are no studies that have considered how to recover the valuable metals for re-use which is an important topic that needs further research.

New research directions started in the last few years for GO hybridizations with different organics to enhance the metal uptake and speed the adsorption kinetics. More detailed mechanistic studies have been utilizing UV and ultrasound to facilitate the adsorption process.

More research is required on new functional groups and composites that increase the maximum adsorption capacity of GO and improve its reusability. More fixed bed column studies are required and both testing of the graphene materials for selective removal of metals is still absent from the current literature as the current studies focus on testing single metals. Moreover, the effect of water salinity on the adsorption of heavy metals is important for treatment of oil- and gas-produced water, where high concentrations of monovalent salts exist. Another key issue is the ability to regenerate and retain the adsorption capacity of the GO-based adsorbent in an economic manner and recover the desorbed metal (in most cases as a precipitated pure salt) for reuse. There are almost no studies which have utilized the use of fixed bed columns experiments as almost all studies have been on batch experiments. Further studies in this area and scale-up are also required with estimation of the cost of the material and its impact on the economic viability of large-scale adsorption processes.

Funding: This research received no external funding.

Acknowledgments: The publication of this article was funded by the Qatar National Library.

Conflicts of Interest: The authors declare no conflict of interest.

\section{References}

1. WHO Guidelines Approved by the Guidelines Review Committee. Guidelines for Drinking-Water Quality: Fourth Edition Incorporating the First Addendum; World Health Organization: Geneva, Switzerland, 2017.

2. Ying, X.; Fang, Z. Experimental research on heavy metal wastewater treatment with dipropyl dithiophosphate. J. Hazard. Mater. 2006, 137, 1636-1642. [CrossRef] [PubMed]

3. Da browski, A.; Hubicki, Z.; Podkościelny, P.; Robens, E. Selective removal of the heavy metal ions from waters and industrial wastewaters by ion-exchange method. Chemosphere 2004, 56, 91-106. [CrossRef]

4. Ahmad, A.L.; Kusumastuti, A.; Derek, C.J.C.; Ooi, B.S. Emulsion liquid membrane for heavy metal removal: An overview on emulsion stabilization and destabilization. Chem. Eng. J. 2011, 171, 870-882. [CrossRef]

5. Deliyanni, E.A.; Kyzas, G.Z.; Matis, K.A. Various flotation techniques for metal ions removal. J. Mol. Liq. 2017, 225, 260-264. [CrossRef]

6. Shafaei, A.; Rezayee, M.; Arami, M.; Nikazar, M. Removal of $\mathrm{Mn}^{2+}$ ions from synthetic wastewater by electrocoagulation process. Desalination 2010, 260, 23-28. [CrossRef]

7. McKay, G. Use of Adsorbents for the Removal of Pollutants from Wastewater; CRC Press: Boca Raton, FL, USA, 1995; p. 208.

8. Abbas, M.; Kaddour, S.; Trari, M. Kinetic and equilibrium studies of cobalt adsorption on apricot stone activated carbon. J. Ind. Eng. Chem. 2014, 20, 745-751. [CrossRef] 
9. Largitte, L.; Brudey, T.; Tant, T.; Dumesnil, P.C.; Lodewyckx, P. Comparison of the adsorption of lead by activated carbons from three lignocellulosic precursors. Microporous Mesoporous Mater. 2016, 219, 265-275. [CrossRef]

10. Abbas, I.A.; Al-Amer, A.M.; Laoui, T.; Al-Marri, M.J.; Nasser, M.S.; Khraisheh, M.; Atieh, M.A. Heavy metal removal from aqueous solution by advanced carbon nanotubes: Critical review of adsorption applications. Sep. Purif. Technol. 2016, 157, 141-161. [CrossRef]

11. Xu, J.; Cao, Z.; Zhang, Y.; Yuan, Z.; Lou, Z.; Xu, X.; Wang, X. A review of functionalized carbon nanotubes and graphene for heavy metal adsorption from water: Preparation, application, and mechanism. Chemosphere 2018, 195, 351-364. [CrossRef]

12. Zhang, L.; Zeng, Y.; Cheng, Z. Removal of heavy metal ions using chitosan and modified chitosan: A review. J. Mol. Liq. 2016, 214, 175-191. [CrossRef]

13. O'Connell, D.W.; Birkinshaw, C.; O'Dwyer, T.F. Heavy metal adsorbents prepared from the modification of cellulose: A review. Bioresour. Technol. 2008, 99, 6709-6724. [CrossRef] [PubMed]

14. Perreault, F.; De Faria, A.F.; Elimelech, M. Environmental applications of graphene-based nanomaterials. Chem. Soc. Rev. 2015, 44, 5861-5896. [CrossRef] [PubMed]

15. Sweetman, M.J.; May, S.; Mebberson, N.; Pendleton, P.; Vasilev, K.; Plush, S.E.; Hayball, J.D. Activated carbon, carbon nanotubes and graphene: Materials and composites for advanced water purification. C J. Carbon Res. 2017, 3, 18. [CrossRef]

16. BC, B. On the atomic weight of graphite. Philos. Trans. R. Soc. Lond. 1859, 149, 249-259.

17. Hummers, W.S., Jr.; Offeman, R.E. Preparation of graphitic oxide. J. Am. Chem. Soc. 1958, 80, 1339. [CrossRef]

18. Zaaba, N.I.; Foo, K.L.; Hashim, U.; Tan, S.J.; Liu, W.-W.; Voon, C.H. Synthesis of Graphene Oxide using Modified Hummers Method: Solvent Influence. Procedia Eng. 2017, 184, 469-477. [CrossRef]

19. Marcano, D.C.; Kosynkin, D.V.; Berlin, J.M.; Sinitskii, A.; Sun, Z.; Slesarev, A.; Alemany, L.B.; Lu, W.; Tour, J.M. Improved Synthesis of Graphene Oxide. ACS Nano 2010, 4, 4806-4814. [CrossRef]

20. Jimenez-Cervantes, E.; Amieva, J.L.B.; Martínez-Hernández, A.L.; Velasco-Santos, C. Graphene-Based Materials Functionalization with Natural Polymeric Biomolecules. In Recent Advances in Graphene Research; Nayak, P.K., Ed.; IntechOpen: London, UK, 2016. [CrossRef]

21. Alazmi, A.; Rasul, S.; Patole, S.P.; Costa, P.M.F.J. Comparative Study of Synthesis and Reduction Methods for Graphene Oxide. Polyhedron 2016, 116, 153-161. [CrossRef]

22. Park, C.M.; Wang, D.; Jonghun, H.; Heo, J.; Su, C. Evaluation of the Colloidal Stability and Adsorption Performance of Reduced Graphene Oxide-Elemental Silver/Magnetite Nanohybrids for Selected Toxic Heavy Metals in Aqueous Solutions. Appl. Surf. Sci. 2018, 8, 471. [CrossRef]

23. Khatamian, M.; Khodakarampoor, N.; Saket-Oskoui, M. Efficient removal of arsenic using graphene-zeolite based composites. J. Colloid Interface Sci. 2017, 498, 433-441. [CrossRef]

24. Choong, C.; Lee, G.; Jang, M.; Park, C.; Ibrahim, S. One Step Hydrothermal Synthesis of Magnesium Silicate Impregnated Palm Shell Waste Activated Carbon for Copper Ion Removal. Metals 2018, 8, 741. [CrossRef]

25. Lujanienè, G.; Šemčuk, S.; Lečinskytè, A.; Kulakauskaitè, I.; Mažeika, K.; Valiulis, D.; Pakštas, V.; Skapas, M.; Tumenas, S. Magnetic graphene oxide based nano-composites for removal of radionuclides and metals from contaminated solutions. J. Environ. Radioact. 2017, 166, 166-174. [CrossRef] [PubMed]

26. Varadwaj, G.B.B.; Oyetade, O.A.; Rana, S.; Martincigh, B.S.; Jonnalagadda, S.B.; Nyamori, V.O. Facile Synthesis of Three-Dimensional Mg-Al Layered Double Hydroxide/Partially Reduced Graphene Oxide Nanocomposites for the Effective Removal of $\mathrm{Pb}^{2+}$ from Aqueous Solution. ACS Appl. Mater. Interfaces 2017, 9, 17291-17306. [CrossRef] [PubMed]

27. Wang, Y.; He, Q.; Qu, H.; Zhang, X.; Guo, J.; Zhu, J.; Zhao, G.; Colorado, H.A.; Yu, J.; Sun, L. Magnetic graphene oxide nanocomposites: Nanoparticles growth mechanism and property analysis. J. Mater. Chem. C 2014, 2, 9478-9488. [CrossRef]

28. Shen, J.; Shi, M.; Ma, H.; Yan, B.; Li, N.; Ye, M. Hydrothermal synthesis of magnetic reduced graphene oxide sheets. Mater. Research Bulletin 2011, 46, 2077-2083. [CrossRef]

29. Wen, T.; Wu, X.; Liu, M.; Xing, Z.; Wang, X.; Xu, A.-W. Efficient Capture of Strontium from Aqueous Solutions Using Graphene Oxide-Hydroxyapatite Nanocomposites. Dalton Trans. 2014, 43, 7464-7472. [CrossRef]

30. Lingamdinne, L.; Kim, I.; Ha, J.; Chang, Y.; Koduru, J.; Yang, J. Enhanced Adsorption Removal of Pb (II) and Cr (III) by Using Nickel Ferrite-Reduced Graphene Oxide Nanocomposite. Metals 2017, 7, 225. [CrossRef] 
31. Ali, M.E.A. Synthesis and Adsorption Properties of Chitosan-CDTA-GO Nanocomposite for Removal of Hexavalent Chromium from Aqueous Solutions, Arabian Journal of Chemistry. Arab. J. Chem. 2018, 11, 1107-1116. [CrossRef]

32. Yang, Y.; Wu, W.; Zhou, H.; Huang, Z.; Ye, T.; Liu, R.; Kuang, Y. Adsorption behavior of cross-linked chitosan modified by graphene oxide for Cu (II) removal. J. Cent. South Univ. 2014, 21, 2826-2831. [CrossRef]

33. Sun, W.; Li, L.; Luo, C.; Fan, L. Synthesis of magnetic graphene nanocomposites decorated with ionic liquids for fast lead ion removal. Int. J. Biol. Macromol. 2016, 85, 246-251. [CrossRef]

34. Zhou, C.; Zhu, H.; Wang, Q.; Wang, J.; Cheng, J.; Guo, Y.; Zhou, X.; Bai, R. Adsorption of mercury (II) with an $\mathrm{Fe}_{3} \mathrm{O}_{4}$ magnetic polypyrrole-graphene oxide nanocomposite. RSC Adv. 2017, 7, 18466-18479. [CrossRef]

35. Yang, J.; Wu, J.-X.; Lü, Q.-F.; Lin, T.-T. Facile preparation of lignosulfonate-graphene oxide-polyaniline ternary nanocomposite as an effective adsorbent for $\mathrm{Pb}$ (II) ions. ACS Sustain. Chem. Eng. 2014, 2, 1203-1211. [CrossRef]

36. Tadjarodi, A.; Ferdowsi, S.; Zare-Dorabei, R.; Barzin, A. Highly efficient ultrasonic-assisted removal of $\mathrm{Hg}$ (II) ions on graphene oxide modified with 2-pyridinecarboxaldehyde thiosemicarbazone: Adsorption isotherms and kinetics studies. Ultrason. Sonochem. 2016, 33, 118-128. [CrossRef]

37. Dinda, D.; Saha, S. Sulfuric acid doped poly diaminopyridine/graphene composite to remove high concentration of toxic Cr (VI). J. Hazard. Mater. 2015, 291, 93-101. [CrossRef] [PubMed]

38. Najafabadi, H.; Irani, M.; Rad, L.; Haratameh, A.; Haririan, I. Removal of $\mathrm{Cu}^{2+}, \mathrm{Pb}^{2+}$ and $\mathrm{Cr}^{6+}$ from aqueous solutions using a chitosan/graphene oxide composite nanofibrous adsorbent. RSC Adv. 2015, 5, 16532-16539. [CrossRef]

39. Li, X.; Wang, S.; Liu, Y.; Jiang, L.; Song, B.; Li, M.; Zeng, G.; Tan, X.; Cai, X.; Ding, Y. Adsorption of Cu (II), $\mathrm{Pb}$ (II), and Cd (II) Ions from Acidic Aqueous Solutions by Diethylenetriaminepentaacetic Acid-Modified Magnetic Graphene Oxide. J. Chem. Eng. Data 2017, 62, 407-416. [CrossRef]

40. Zare-Dorabei, R.; Ferdowsi, S.; Barzin, A.; Tadjarodi, A. Highly efficient simultaneous ultrasonic-assisted adsorption of $\mathrm{Pb}$ (II), $\mathrm{Cd}$ (II), $\mathrm{Ni}$ (II) and $\mathrm{Cu}$ (II) ions from aqueous solutions by graphene oxide modified with 2,2 '-dipyridylamine: Central composite design optimization. Ultrason. Sonochem. 2016, 32, 265-276. [CrossRef]

41. Wan, S.; He, F.; Wu, J.; Wan, W.; Gu, Y.; Gao, B. Rapid and highly selective removal of lead from water using graphene oxide-hydrated manganese oxide nanocomposites. J. Hazard. Mater. 2016, 314, 32-40. [CrossRef]

42. $\mathrm{Fu}, \mathrm{W}$; Wang, X.; Huang, Z. Remarkable reusability of magnetic $\mathrm{Fe}_{3} \mathrm{O}_{4}$-encapsulated $\mathrm{C}_{3} \mathrm{~N}_{3} \mathrm{~S}_{3}$ polymer/reduced graphene oxide composite: A highly effective adsorbent for $\mathrm{Pb}$ and $\mathrm{Hg}$ ions. Sci. Total Environ. 2019, 659, 895-904. [CrossRef]

43. Rao, C.N.R.; Maitra, U.; Matte, H.S.S.R. Synthesis, Characterization, and Selected Properties of Graphene. In Graphene; Sood, C.N.R.R.A.A.K., Ed.; Wiley: Hoboken, NJ, USA, 2012; pp. 1-47. [CrossRef]

44. Alimohammady, M.; Jahangiri, M.; Kiani, F.; Tahermansouri, H. Highly efficient simultaneous adsorption of Cd (II), $\mathrm{Hg}$ (II) and As (III) ions from aqueous solutions by modification of graphene oxide with 3-aminopyrazole: Central composite design optimization. New J. Chem. 2017, 41, 8905-8919. [CrossRef]

45. Verduzco, J.; Oliva, A.I.; Oliva, E.; Macias, C.R.; Garcia, M.; Herrera-Trejo, N.; Pariona, A.I. Enhanced Removal of Arsenic and Chromium Contaminants from Drinking Water by Electrodeposition Technique Using Graphene Composites. Mater. Chem. Phys. 2019, 229, 197-209. [CrossRef]

46. Shahzad, A.; Miran, W.; Rasool, K.; Nawaz, M.; Jang, J.; Lim, S.; Lee, D. Heavy metals removal by EDTA-functionalized chitosan graphene oxide nanocomposites. RSC Adv. 2017, 7, 9764-9771. [CrossRef]

47. Awad, F.S.; AbouZeid, K.M.; Abou El-Maaty, W.M.; El-Wakil, A.M.; El Shall, M.S. Efficient Removal of Heavy Metals from Polluted Water with High Selectivity for Mercury (II) by 2-lmino-4-thiobiuret-Partially Reduced Graphene Oxide (IT-PRGO). ACS Appl. Mater. Interfaces 2017, 9, 34230-34242. [CrossRef] [PubMed]

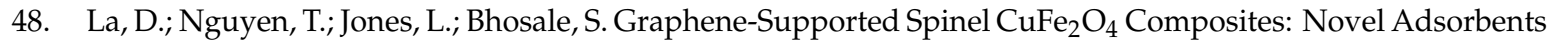
for Arsenic Removal in Aqueous Media. Sensors 2017, 17, 1292. [CrossRef]

49. Su, H.; Ye, Z.; Hmidi, N. High-performance iron oxide-graphene oxide nanocomposite adsorbents for arsenic removal. Colloids Surf. A-Physicochem. Eng. Asp. 2017, 522, 161-172. [CrossRef]

50. Dubey, S.; Nguyen, T.; Kwon, Y.; Lee, C. Synthesis and characterization of metal-doped reduced graphene oxide composites, and their application in removal of Escherichia coli, arsenic and 4-nitrophenol. J. Ind. Eng. Chem. 2015, 29, 282-288. [CrossRef] 
51. Yoon, Y.; Zheng, M.; Ahn, Y.; Park, W.; Yang, W.; Kang, J. Synthesis of magnetite/non-oxidative graphene composites and their application for arsenic removal. Sep. Purif. Technol. 2017, 178, 40-48. [CrossRef]

52. Wen, T.; Wu, X.; Tan, X.; Wang, X.; Xu, A. One-Pot Synthesis of Water-Swellable Mg-Al Layered Double Hydroxides and Graphene Oxide Nanocomposites for Efficient Removal of As (V) from Aqueous Solutions. ACS Appl. Mater. Interfaces 2013, 5, 3304-3311. [CrossRef]

53. Wang, X.; Pei, Y.; Lu, M.; Lu, X.; Du, X. Highly efficient adsorption of heavy metals from wastewaters by graphene oxide-ordered mesoporous silica materials. J. Mater. Sci. 2015, 50, 2113-2121. [CrossRef]

54. Sreeram, A.; Hadi, P.; Hui, D.; Al Ansari, T.; McKay, G. Optimisation of the removal of arsenate from water using nanochitosan. Desalin. Water Treat. 2017, 70, 235-243. [CrossRef]

55. Boddu, V.M.; Abburi, K.; Talbott, J.L.; Smith, E.D.; Haasch, R. Removal of Arsenic (III) and Arsenic (V) from Aqueous Medium Using Chitosan-Coated Biosorbent. Water Res. 2008, 42, 633-642. [CrossRef] [PubMed]

56. Yu, X.; Tong, S.; Ge, M.; Wu, L.; Zuo, J.; Cao, C.; Song, W. Synthesis and Characterization of Multi-Amino-Functionalized Cellulose for Arsenic Adsorption. Carbohydr. Polym. 2013, 92, 380-387. [CrossRef] [PubMed]

57. Kamsonlian, S.; Suresh, S.; Ramanaiah, V.; Majumder, C.B.; Chand, S.; Kumar, A. Biosorptive Behavior of Mango Leaf Powder and Rice Husk for Arsenic (III) From Aqueous Solutions. Int. J. Environ. Sci. Technol. 2012, 9, 565-578. [CrossRef]

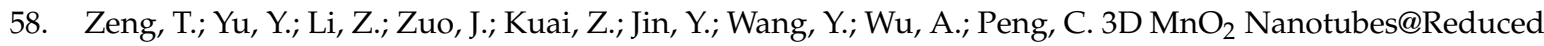
Graphene Oxide Hydrogel as Reusable Adsorbent for the Removal of Heavy Metal Ions. Mater. Chem. Phys. 2019, 231, 105-108. [CrossRef]

59. Mohan, S.; Kumar, V.; Singh, D.K.; Hasan, S.H. Effective removal of lead ions using graphene oxide-MgO nanohybrid from aqueous solution: Isotherm, kinetic and thermodynamic modeling of adsorption. J. Environ. Chem. Eng. 2017, 5, 2259-2273. [CrossRef]

60. Santhosh, C.; Kollu, P.; Felix, S.; Velmurugan, V.; Jeong, S.; Grace, A. $\mathrm{CoFe}_{2} \mathrm{O}_{4}$ and $\mathrm{NiFe}_{2} \mathrm{O}_{4} @$ graphene adsorbents for heavy metal ions - kinetic and thermodynamic analysis. RSC Adv. 2015, 5, 28965-28972. [CrossRef]

61. Prasad, C.; Murthy, P.K.; Krishna, R.H.; Rao, R.S.; Suneetha, V.; Venkateswarlu, P. Bio-inspired green synthesis of $\mathrm{RGO} / \mathrm{Fe}_{3} \mathrm{O}_{4}$ magnetic nanoparticles using Murrayakoenigii leaves extract and its application for removal of $\mathrm{Pb}$ (II) from aqueous solution. J. Environ. Chem. Eng. 2017, 5, 4374-4380. [CrossRef]

62. Nasiri, N.; Arsalani, Y.; Pirveysian, M. One-Pot Synthesis of Novel Magnetic Three-Dimensional Graphene/Chitosan/Nickel Ferrite Nanocomposite for Lead Ions Removal from Aqueous Solution: RSM Modelling Design. J. Clean. Prod. 2018, 201, 507-515. [CrossRef]

63. Ge, H.; Zou, W. Preparation and characterization of L-glutamic acid-functionalized graphene oxide for adsorption of $\mathrm{Pb}$ (II). J. Dispers. Sci. Technol. 2017, 38, 241-247. [CrossRef]

64. Yang, Y.; Xie, Y.; Pang, L.; Li, M.; Song, X.; Wen, J.; Zhao, H. Preparation of Reduced Graphene Oxide/Poly (acrylamide) Nanocomposite and Its Adsorption of $\mathrm{Pb}$ (II) and Methylene Blue. Langmuir 2013, 29, 10727-10736. [CrossRef]

65. Hu, Z.; Qin, S.; Huang, Z.; Zhu, Y.; Xi, L.; Li, Z. Stepwise synthesis of graphene oxide-wrapped magnetic composite and its application for the removal of $\mathrm{Pb}$ (II). Arab. J. Sci. Eng. 2017, 42, 4239-4247. [CrossRef]

66. Zhang, F.; Song, Y.; Song, S.; Zhang, R.; Hou, W. Synthesis of Magnetite-Graphene Oxide-Layered Double Hydroxide Composites and Applications for the Removal of $\mathrm{Pb}$ (II) and 2, 4-Dichlorophenoxyacetic Acid from Aqueous Solutions. ACS Appl. Mater. Interfaces 2015, 7, 7251-7263. [CrossRef] [PubMed]

67. Yao, M.; Wang, Z.; Liu, Y.; Yang, G.; Chen, J. Preparation of Dialdehyde Cellulose Grafted Graphene Oxide Composite and Its Adsorption Behavior for Heavy Metals from Aqueous Solution. Carbohydr. Polym. 2019, 212, 345-351. [CrossRef] [PubMed]

68. Fu, W.; Huang, Z. Magnetic Dithiocarbamate Functionalized Reduced Graphene Oxide for the Removal of $\mathrm{Cu}$ (II), Cd (II), Pb (II), And Hg (II) Ions from Aqueous Solution: Synthesis, Adsorption, and Regeneration. Chemosphere 2018, 209, 449-456. [CrossRef] [PubMed]

69. Ghasemabadi, M.; Baghdadi, E.; Safari, F. Investigation of Continuous Adsorption of Pb (II), As (III), Cd (II), and $\mathrm{Cr}$ (VI) using a Mixture of Magnetic Graphite Oxide and Sand as a Medium in a Fixed-Bed Column. J. Environ. Chem. Eng. 2018, 6, 4840-4849. [CrossRef] 
70. Peer, N.; Bahramifar, H. Removal of Cd (II), $\mathrm{Pb}$ (II) and Cu (II) Ions from Aqueous Solution by Polyamidoamine Dendrimer Grafted Magnetic Graphene Oxide Nanosheets. J. Taiwan Inst. Chem. Eng. 2018, 87, 225-240. [CrossRef]

71. Albert, E.; Abdullah, C.; Shiroshaki, Y. Synthesis and Characterization of Graphene Oxide Functionalized With Magnetic Nanoparticle via Simple Emulsion Method. Results Phys. 2018, 11, 944-950. [CrossRef]

72. Samuel, M.S.; Shah, S.S.; Bhattacharya, J.; Subramaniam, K.; Pradeep Singh, N.D. Adsorption of Pb (II) from Aqueous Solution Using a Magnetic Chitosan/Graphene Oxide Composite and Its Toxicity Studies. Int. J. Biol. Macromol. 2018, 115, 1142-1150. [CrossRef]

73. Cai, Y.; Jiang, Y.; Feng, L.; Hua, Y.; Liu, H.; Fan, C.; Yin, M.; Li, S.; Lv, X.; Wang, H. Q-Graphene-Scaffolded Covalent Organic Frameworks as Fluorescent Probes and Sorbents for the Fluorimetry and Removal of Copper Ions. Anal. Chim. Acta 2019, 1057, 88-97. [CrossRef]

74. Cao, X.; Wen, J.; Wang, F.; Yang, H.; Zhong, S.; Wang, Z.; Surfaces, A. In situ Nano-Fe $3 \mathrm{O}_{4} /$ Triisopropanolamine Functionalized Graphene Oxide Composites to Enhance $\mathrm{Pb}^{2+}$ Ions Removal. Colloids Physicochem. Eng. Asp. 2019, 561, 209-217. [CrossRef]

75. Vafajoo, R.; Cheraghi, R.; Dabbagh, G. Removal of Cobalt (II) Ions from Aqueous Solutions Utilizing the Pre-Treated 2-Hypnea Valentiae Algae: Equilibrium, Thermodynamic, and Dynamic Studies. Chem. Eng. J. 2018, 331, 39-47. [CrossRef]

76. Cui, L.; Wang, Y.; Gao, L.; Hu, L.; Yan, L.; Wei, Q.; Du, B. EDTA functionalized magnetic graphene oxide for removal of $\mathrm{Pb}$ (II), $\mathrm{Hg}$ (II) and $\mathrm{Cu}$ (II) in water treatment: Adsorption mechanism and separation property. Chem. Eng. J. 2015, 281, 1-10. [CrossRef]

77. Guo, X.; Du, B.; Wei, Q.; Yang, J.; Hu, L.; Yan, L.; Xu, W. Synthesis of amino functionalized magnetic graphenes composite material and its application to remove $\mathrm{Cr}$ (VI), $\mathrm{Pb}$ (II), $\mathrm{Hg}$ (II), Cd (II) and $\mathrm{Ni}$ (II) from contaminated water. J. Hazard. Mater. 2014, 278, 211-220. [CrossRef] [PubMed]

78. Raghubanshi, H.; Ngobeni, S.; Osikoya, A.; Shooto, N.; Dikio, C.; Naidoo, E.; Dikio, E.; Pandey, R.; Prakash, R. Synthesis of graphene oxide and its application for the adsorption of $\mathrm{Pb}^{+2}$ from aqueous solution. J. Ind. Eng. Chem. 2017, 47, 169-178. [CrossRef]

79. Hemidouche, S.; Boudriche, L.; Boudjemaa, A.; Hamoudi, S. Removal of Lead (II) and Cadmium (II) Cations from Water Using Surface-Modified Graphene. Can. J. Chem. Eng. 2017, 95, 508-515. [CrossRef]

80. Mahto, A.; Kumar, A.; Bhatt, M.; Chaudhary, J.; Sharma, A.; Paul, P.; Sanna Kotrappanavar, N.; Meena, R. Solvent-free production of nano-FeS anchored Graphene from Ulva fasciata: A Scalable synthesis of super-adsorbent for lead, chromium and dyes. J. Hazard. Mater. 2018, 353. [CrossRef]

81. Wei, M.-P.; Chai, H.; Cao, Y.-L.; Jia, D.-Z. Sulfonated Graphene Oxide as an Adsorbent for Removal of $\mathrm{Pb}^{+2}$ and Methylene Blue. J. Colloid Interface Sci. 2018, 524, 297-305. [CrossRef]

82. Wang, J.; Li, Y.; Lv, Z.; Xie, Y.; Shu, J.; Alsaedi, A.; Hayat, T.; Chen, C. Exploration of the Adsorption Performance and Mechanism of Zeolitic Imidazolate Framework-8@Graphene Oxide for Pb (II) and 1-Naphthylamine from Aqueous Solution. J. Colloid Interface Sci. 2019, 542, 410-420. [CrossRef]

83. Pirveysian, M.; Ghiaci, M. Synthesis and Characterization of Sulfur Functionalized Graphene Oxide Nanosheets as Efficient Sorbent For Removal of $\mathrm{Pb}^{2+}, \mathrm{Cd}^{2+}, \mathrm{Ni}^{2+}$ and $\mathrm{Zn}^{2+}$ Ions from Aqueous Solution: A Combined Thermodynamic and Kinetic Studies. Appl. Surf. Sci. 2018, 428, 98-109. [CrossRef]

84. Kong, L.; Li, Z.C.; Huang, X.Q.; Huang, S.Q.; Sun, H.; Liu, M.; Li, L. Efficient removal of Pb (II) from water using magnetic $\mathrm{Fe}_{3} \mathrm{~S}_{4}$ /reduced graphene oxide composites. J. Mater. Chem. A 2017, 5, 19333-19342. [CrossRef]

85. Santhosh, C.; Nivetha, R.; Kollu, P.; Srivastava, V.; Sillanpää, M.; Grace, A.N.; Bhatnagar, A. Removal of cationic and anionic heavy metals from water by $1 \mathrm{D}$ and $2 \mathrm{D}$-carbon structures decorated with magnetic nanoparticles. Sci. Rep. 2017, 7, 1-11. [CrossRef] [PubMed]

86. Rahimi, E.; Mohaghegh, N. New hybrid nanocomposite of copper terephthalate MOF-graphene oxide: Synthesis, characterization and application as adsorbents for toxic metal ion removal from Sungun acid mine drainage. Environ. Sci. Pollut. Res. 2017, 24, 22353-22360. [CrossRef] [PubMed]

87. Sahoo, A.; Srivastava, S.; Raul, P.; Gupta, A.; Shrivastava, R. Graphene nanocomposites of CdS and ZnS in effective water purification. J. Nanopart. Res. 2014, 16. [CrossRef]

88. Lingamdinne, L.; Koduru, J.; Choi, Y.; Chang, Y.; Yang, J. Studies on removal of Pb (II) and Cr (III) using graphene oxide based inverse spinel nickel ferrite nano-composite as sorbent. Hydrometallurgy 2016, 165, 64-72. [CrossRef] 
89. La, D.D.; Thi, H.P.N.; Nguyen, T.A.; Bhosale, S.V. Effective removal of $\mathrm{Pb}$ (II) using a graphene@ternary oxides composite as an adsorbent in aqueous media. New J. Chem. 2017, 41, 14627-14634. [CrossRef]

90. Zhao, X.; Hu, B.; Ye, J.; Jia, Q. Preparation, Characterization, and Application of Graphene-Zinc Oxide Composites (G-ZnO) for the Adsorption of $\mathrm{Cu}$ (II), $\mathrm{Pb}$ (II), and Cr (III). J. Chem. Eng. Data 2013, 58, 2395-2401. [CrossRef]

91. Zhan, W.; Gao, L.; Fu, X.; Siyal, S.H.; Sui, G.; Yang, X. Green Synthesis of Amino-Functionalized Carbon Nanotube-Graphene Hybrid Aerogels for High Performance Heavy Metal Ions Removal. Appl. Surf. Sci. 2019, 467, 1122-1133. [CrossRef]

92. Gao, T.; Yu, J.; Zhou, Y.; Jiang, X. The synthesis of graphene oxide functionalized with dithiocarbamate group and its prominent performance on adsorption of lead ions. J. Taiwan Inst. Chem. Eng. 2017, 71, 426-432. [CrossRef]

93. Wang, Y.; Li, L.; Luo, C.; Wang, X.; Duan, H. Removal of $\mathrm{Pb}^{2+}$ from water environment using a novel magnetic chitosan/graphene oxide imprinted $\mathrm{Pb}^{2+}$. Int. J. Biol. Macromol. 2016, 86, 505-511. [CrossRef]

94. Fan, L.; Luo, C.; Sun, M.; Li, X.; Qiu, H. Highly selective adsorption of lead ions by water-dispersible magnetic chitosan/graphene oxide composites. Colloids Surf. B Biointerfaces 2013, 103, 523-529. [CrossRef]

95. Ma, Y.X.; Kou, Y.L.; Xing, D.; Jin, P.S.; Shao, W.J.; Li, X.; Du, X.Y.; La, P.Q. Synthesis of magnetic graphene oxide grafted polymaleicamide dendrimer nanohybrids for adsorption of $\mathrm{Pb}$ (II) in aqueous solution. J. Hazard. Mater. 2017, 340, 407-416. [CrossRef] [PubMed]

96. Yakout, A.A.; El-Sokkary, R.H.; Shreadah, M.A.; Hamid, O.G.A. Cross-linked graphene oxide sheets via modified extracted cellulose with high metal adsorption. Carbohydr. Polym. 2017, 172, 20-27. [CrossRef] [PubMed]

97. Hao, J.; Ji, L.; Li, C.; Hu, C.; Wu, K. Rapid, Efficient and Economic Removal of Organic Dyes and Heavy Metals from Wastewater by Zinc-Induced In-Situ Reduction and Precipitation of Graphene Oxide. J. Taiwan Inst. Chem. Eng. 2018, 88, 137-145. [CrossRef]

98. Arshad, M.; Selvaraj, J.; Zain, F.; Banat, M.A. Polyethylenimine Modified Graphene Oxide Hydrogel Composite as an Efficient Adsorbent for Heavy Metal Ions, Separation and Purification Technology. Sep. Purif. Technol. 2019, 209, 870-880. [CrossRef]

99. Wang, B.; Zhang, F.; He, S.; Huang, F.; Peng, Z. Adsorption Behaviour of Reduced Graphene Oxide for Removal of Heavy Metal Ions. Asian J. Chem. 2014, 26, 4901-4906. [CrossRef]

100. Wang, Y.; Liang, S.; Chen, B.; Guo, F.; Yu, S.; Tang, Y. Synergistic Removal of Pb (II), Cd (II) and Humic Acid by $\mathrm{Fe}_{3} \mathrm{O}_{4} @$ Mesoporous Silica-Graphene Oxide Composites. PLoS ONE 2013, 8. [CrossRef]

101. Luo, S.; Xu, X.; Zhou, G.; Liu, C.; Tang, Y.; Liu, Y. Amino siloxane oligomer-linked graphene oxide as an efficient adsorbent for removal of $\mathrm{Pb}$ (II) from wastewater. J. Hazard. Mater. 2014, 274, 145-155. [CrossRef]

102. Aliyari, E.; Alvand, M.; Shemirani, F. Simultaneous separation and preconcentration of lead and cadmium from water and vegetable samples using a diethylenetriamine-modified magnetic graphene oxide nanocomposite. Anal. Methods 2015, 7, 7582-7589. [CrossRef]

103. Song, X.; Liu, H.; Cheng, L.; Qu, Y. Surface Modification of Coconut-Based Activated Carbon by Liquid-Phase Oxidation and Its Effects on Lead Ion Adsorption. Desalination 2010, 255, 78-83. [CrossRef]

104. Lalhruaitluanga, H.; Jayaram, K.; Prasad, M.; Kumar, K. Lead (II) Adsorption from Aqueous Solutions by Raw and Activated Charcoals of Melocanna Baccifera Roxburgh (Bamboo)-A Comparative Study. J. Hazard. Mater. 2010, 175, 311-318. [CrossRef]

105. Ng, J.; Cheung, W.; McKay, G. Equilibrium Studies for the Sorption of Lead from Effluents Using Chitosan. Chemosphere 2003, 52, 1021-1030. [CrossRef]

106. Ho, Y.-S.; McKay, G. The Kinetics of Sorption of Divalent Metal Ions onto Sphagnum Moss Peat. Water Res. 2000, 34, 735-742. [CrossRef]

107. Hadi, P.; Barford, J.; McKay, G. Selective Toxic Metal Uptake Using an E-Waste-Based Novel Sorbent-Single, Binary and Ternary Systems. J. Environ. Chem. Eng. 2014, 2, 332-339. [CrossRef]

108. Bouabidi, Z.B.; El-Naas, M.H.; Cortes, D.; McKay, G. Steel-Making Dust as a Potential Adsorbent for the Removal of Lead (II) from an Aqueous Solution. Chem. Eng. J. 2018, 334, 837-844. [CrossRef]

109. Li, J.; Chen, C.; Zhu, K.; Wang, X. Nanoscale zero-valent iron particles modified on reduced graphene oxides using a plasma technique for Cd (II) removal. J. Taiwan Inst. Chem. Eng. 2016, 59, 389-394. [CrossRef] 
110. Demirbas, A.; Pehlivan, E.; Gode, F.; Altun, T.; Arslan, G. Adsorption of Cu (II), Zn (II), Ni (II), Pb (II), and Cd (II) From Aqueous Solution on Amberlite IR-120 Synthetic Resin. J. Colloid Interface Sci. 2005, 282, $20-25$. [CrossRef]

111. Karnitz, O., Jr.; Gurgel, L.V.A.; De Melo, J.C.P.; Botaro, V.R.; Melo, T.M.S.; De Freitas Gil, R.P.; Gil, L.F. Adsorption of Heavy Metal Ion from Aqueous Single Metal Solution by Chemically Modified Sugarcane Bagasse. Bioresour. Technol. 2007, 98, 1291-1297. [CrossRef]

112. Corami, A.; Mignardi, S.; Ferrini, V. Cadmium Removal from Single-And Multi-Metal $\left(\mathrm{Cd}^{+} \mathrm{Pb}^{+} \mathrm{Zn}^{+} \mathrm{Cu}\right)$ Solutions by Sorption on Hydroxyapatite. J. Colloid Interface Sci. 2008, 317, 402-408. [CrossRef]

113. Yang, G.; Tang, L.; Lei, X.; Zeng, G.; Cai, Y.; Wei, X.; Zhou, Y.; Li, S.; Fang, Y.; Zhang, Y. Cd (II) Removal from Aqueous Solution by Adsorption on $\alpha$-Ketoglutaric Acid-Modified Magnetic Chitosan. Appl. Surf. Sci. 2014, 292, 710-716. [CrossRef]

114. Xu, M.; Hadi, P.; Ning, C.; Barford, J.; An, K.J.; McKay, G. Aluminosilicate-Based Adsorbent in Equimolar and Non-Equimolar Binary-Component Heavy Metal Removal Systems. Water Sci. Technol. 2015, 72, 2166-2178. [CrossRef]

115. Zhao, G.; Li, J.; Ren, X.; Chen, C.; Wang, X. Few-layered graphene oxide nanosheets as superior sorbents for heavy metal ion pollution management. Environ. Sci. Technol. 2011, 45, 10454-10462. [CrossRef] [PubMed]

116. Fan, M.; Li, T.; Hu, J.; Cao, R.; Wei, X.; Shi, X.; Ruan, W. Artificial Neural Network Modeling and Genetic Algorithm Optimization for Cadmium Removal from Aqueous Solutions by Reduced Graphene Oxide-Supported Nanoscale Zero-Valent Iron (nZVI/rGO) Composites. Materials 2017, 10, 544. [CrossRef] [PubMed]

117. Shunli, W.; Ding, W.; Wang, Y.; Wu, J.; Gu, Y.; He, F. Manganese Oxide Nanoparticles Impregnated Graphene Oxide Aggregates for Cadmium and Copper Remediation. Chem. Eng. J. 2018, 350. [CrossRef]

118. Dai, J.Y.; Zhao, H.Y.; Ye, Y.T.; Wang, L.; Cao, S.Y.; Su, X.J.; Hu, X.F.; Li, L. Improving the selectivity of magnetic graphene oxide through amino modification. Water Sci. Technol. 2017, 76, 2959-2967. [CrossRef]

119. Bian, Y.; Bian, Z.; Zhang, J.; Ding, A.; Liu, S.; Wang, H. Effect of the oxygen-containing functional group of graphene oxide on the aqueous cadmium ions removal. Appl. Surf. Sci. 2015, 329, 269-275. [CrossRef]

120. Chen, Y.; Song, X.; Zhao, T.; Xiao, Y.; Wang, Y.; Chen, X. A Phosphorylethanolamine-Functionalized Super-Hydrophilic 3D Graphene-Based Foam Filter for Water Purification. J. Hazard. Mater. 2018, 343, 298-303. [CrossRef]

121. Li, X.; Li, F.; Fang, L. Effect of Paecilomyces cateniannulatus on the adsorption of nickel onto graphene oxide. Korean J. Chem. Eng. 2015, 32, 2449-2455. [CrossRef]

122. Park, S.; Ruoff, R.S. Synthesis and characterization of chemically modified graphenes. Curr. Opin. Colloid Interface Sci. 2015, 20, 322-328. [CrossRef]

123. Hoan, N.; Thu, N.; Van Duc, H.; Cuong, N.; Khieu, D.; Vo, V. $\mathrm{Fe}_{3} \mathrm{O}_{4} /$ Reduced Graphene Oxide Nanocomposite: Synthesis and Its Application for Toxic Metal Ion Removal. J. Chem. 2016. [CrossRef]

124. Konicki, W.; Aleksandrzak, M.; Mijowska, E. Equilibrium and kinetics studies for the adsorption of $\mathrm{Ni}^{2+}$ and $\mathrm{Fe}^{3+}$ ions from aqueous solution by graphene oxide. Pol. J. Chem. Technol. 2017, 19, 120-129. [CrossRef]

125. Gardea-Torresdey, J.; Tiemann, K.; Gonzalez, J.; Cano-Aguilera, I.; Henning, J.; Townsend, M. Removal of Nickel Ions from Aqueous Solution by Biomass and Silica-Immobilized Biomass of Medicago Sativa (Alfalfa). J. Hazard. Mater. 1996, 49, 205-216. [CrossRef]

126. Eser, A.; Tirtom, V.N.; Aydemir, T.; Becerik, S.; Dinçer, A. Removal of Nickel (II) Ions by Histidine Modified Chitosan Beads. Chem. Eng. J. 2012, 210, 590-596. [CrossRef]

127. Zafar, M.N.; Nadeem, R.; Hanif, M.A. Biosorption of Nickel from Protonated Rice Bran. J. Hazard. Mater. 2007, 143, 478-485. [CrossRef] [PubMed]

128. Dawood, S.; Sen, T.K.; Phan, C. Synthesis and Characterization of Slow Pyrolysis Pine Cone Bio-Char in the Removal of Organic and Inorganic Pollutants from Aqueous Solution by Adsorption: Kinetic, Equilibrium, Mechanism and Thermodynamic. Bioresour. Technol. 2017, 246, 76-81. [CrossRef]

129. Qu, Z.; Fang, L.; Chen, D.; Xu, H.; Yan, N. Effective and regenerable Ag/graphene adsorbent for Hg (II) removal from aqueous solution. Fuel 2017, 203, 128-134. [CrossRef]

130. Tang, J.; Huang, Y.; Gong, Y.; Lyu, H.; Wang, Q.; Ma, J. Preparation of a novel graphene oxide/Fe-Mn composite and its application for aqueous $\mathrm{Hg}$ (II) removal. J. Hazard. Mater. 2016, 316, 151-158. [CrossRef] 
131. Gao, Y.; Chen, K.; Tan, X.; Wang, X.; Alsaedi, A.; Hayat, T.; Chen, C. Interaction Mechanism of Re (VII) with Zirconium Dioxide Nanoparticles Archored onto Reduced Graphene Oxides. ACS Sustain. Chem. Eng. 2017, 5, 2163-2171. [CrossRef]

132. Huang, Y.; Gong, Y.; Tang, J.; Xia, S. Effective Removal of Inorganic Mercury and Methylmercury from Aqueous Solution Using Novel Thiol-Functionalized Graphene Oxide/Fe-Mn Composite. J. Hazard. Mater. 2019, 366, 130-139. [CrossRef]

133. Tan, B.; Zhao, H.; Zhang, Y.; Quan, X.; He, Z.; Zheng, W.; Shi, B. Amphiphilic PA-Induced Three-Dimensional Graphene Macrostructure with Enhanced Removal of Heavy Metal Ions. J. Colloid Interface Sci. 2018, 512, 853-861. [CrossRef]

134. Wang, C.; Ge, H.; Zhao, Y.; Liu, S.; Zou, Y.; Zhang, W. Study on the adsorption of Cu (II) by folic acid functionalized magnetic graphene oxide. J. Magn. Magn. Mater. 2017, 423, 421-435. [CrossRef]

135. Chen, B.; Bi, H.C.; Ma, Q.L.; Tan, C.L.; Cheng, H.F.; Chen, Y.; He, X.Y.; Sun, L.T.; Lim, T.T.; Huang, L.; et al. Preparation of graphene- $\mathrm{MoS}_{2}$ hybrid aerogels as multifunctional sorbents for water remediation. Sci. China-Mater. 2017, 60, 1102-1108. [CrossRef]

136. Bhalara, P.D.; Balasubramanian, K.; Banerjee, B.S. Spider-web textured electrospun composite of graphene for sorption of $\mathrm{Hg}$ (II) ions. Mater. Focus 2015, 4, 154-163. [CrossRef]

137. Zhuang, Y.-T.; Jiang, R.; Wu, D.-F.; Yu, Y.-L.; Wang, J.-H. Selenocarrageenan-Inspired Hybrid Graphene Hydrogel as Recyclable Adsorbent for Efficient Scavenging Of Dyes and $\mathrm{Hg}^{2+}$ In Water Environment. J. Colloid Interface Sci. 2019, 540, 572-578. [CrossRef] [PubMed]

138. Yap, P.L.; Tung, T.T.; Kabiri, S.; Matulick, N.; Tran, D.N.; Losic, D. Polyamine-modified reduced graphene oxide: A new and cost-effective adsorbent for efficient removal of mercury in waters. Sep. Purif. Technol. 2020, 238, 116441. [CrossRef]

139. Zabihi, M.; Ahmadpour, A.; Asl, A. Mercury Adsorption on a Carbon Sorbent Derived from Walnut Shell. J Hazard. Mater. 2008, 174, 251-256. [CrossRef] [PubMed]

140. Li, H.; Li, J.; Cheng, L. Novel Cr (III) surface magnetic ion-imprinted materials based on graphene oxide for selective removal of Cr (III) in aqueous solution. Desalin. Water Treat. 2015, 56, 204-215. [CrossRef]

141. Zhang, L.; Luo, H.; Liu, P.; Fang, W.; Geng, J. A novel modified graphene oxide/chitosan composite used as an adsorbent for $\mathrm{Cr}$ (VI) in aqueous solutions. Int. J. Biol. Macromol. 2016, 87, 586-596. [CrossRef] [PubMed]

142. Lingamdinne, J.R.; Koduru, Y.; Chang, R.R. Process Optimization and Adsorption Modeling Of Pb (II) on Nickel Ferrite-Reduced Graphene Oxide Nano-Composite. J. Mol. Liq. 2018, 250, 202-211. [CrossRef]

143. Lei, Y.; Chen, F.; Luo, Y.; Zhang, L. Three-dimensional magnetic graphene oxide foam $/ \mathrm{Fe}_{3} \mathrm{O}_{4}$ nanocomposite as an efficient absorbent for Cr (VI) removal. J. Mater. Sci. 2014, 49, 4236-4245. [CrossRef]

144. Fathi, S.; Kalantary, R.; Rashidi, A.; Karbassi, A. Hexavalent chromium adsorption from aqueous solutions using nanoporous graphene/ $\mathrm{Fe}_{3} \mathrm{O}_{4}\left(\mathrm{NPG} / \mathrm{Fe}_{3} \mathrm{O}_{4}\right.$ : Modeling and optimization). Desalin. Water Treat. 2016, 57, 28284-28293. [CrossRef]

145. Hou, T.; Kong, L.; Guo, X.; Wu, Y.; Wang, F.; Wen, Y.; Yang, H. Magnetic ferrous-doped graphene for improving Cr (VI) removal. Mater. Res. Express 2016, 3. [CrossRef]

146. Harijan, D.; Chandra, V. Environment Friendly Synthesis of Magnetite-Graphene Composite for Adsorption of Toxic Chromium (VI) Ions from Drinking Water. Environ. Prog. Sustain. Energy 2016, 35, 700-705. [CrossRef]

147. Wang, X.; Lu, J.; Cao, B.; Liu, X.; Lin, Z.; Yang, C.; Wu, R.; Su, X.; Wang, X. Facile synthesis of recycling $\mathrm{Fe}_{3} \mathrm{O}_{4}$ /graphene adsorbents with potassium humate for $\mathrm{Cr}(\mathrm{VI})$ removal. Colloids Surf. A: Physicochem. Eng. Asp. 2019, 560, 384-392. [CrossRef]

148. Sun, X.; Chen, F.; Wei, J.; Zhang, F.; Pang, S. Preparation of magnetic triethylene tetramine-graphene oxide ternary nanocomposite and application for Cr (VI) removal. J. Taiwan Inst. Chem. Eng. 2016, 66, 328-335. [CrossRef]

149. Li, L.; Luo, C.; Li, X.; Duan, H.; Wang, X. Preparation of magnetic ionic liquid/chitosan/graphene oxide composite and application for water treatment. Int. J. Biol. Macromol. 2014, 66, 172-178. [CrossRef]

150. Dinda, D.; Gupta, A.; Saha, S. Removal of toxic Cr (VI) by UV-active functionalized graphene oxide for water purification. J. Mater. Chem. A 2013, 1, 11221-11228. [CrossRef]

151. Anush, S.M.; Chandan, H.R.; Vishalakshi, B. Synthesis and Metal Ion Adsorption Characteristics of Graphene Oxide Incorporated Chitosan Schiff Base. Int. J. Biol. Macromol. 2019, 126, 908-916. [CrossRef] 
152. Yu, F.; Li, Y.; Ma, J. Environmental Application and Design of Alginate/Graphene Double-Network Nanocomposite Beads. In New Polymer Nanocomposites for Environmental Remediation; Hussain, C.M., Mishra, A.K., Eds.; Elsevier: Amsterdam, The Netherlands, 2018; pp. 47-76. [CrossRef]

153. Zhu, J.; Wei, S.; Gu, H.; Rapole, S.; Wang, Q.; Luo, Z.; Haldolaarachchige, N.; Young, D.; Guo, Z. One-Pot Synthesis of Magnetic Graphene Nanocomposites Decorated with Core@Double-shell Nanoparticles for Fast Chromium Removal. Environ. Sci. Technol. 2012, 46, 977-985. [CrossRef]

154. Wang, W.; Cai, K.; Wu, X.; Shao, X.; Yang, X. A novel poly(m-phenylenediamine)/reduced graphene oxide/nickel ferrite magnetic adsorbent with excellent removal ability of dyes and Cr (VI). J. Alloys Compd. 2017, 722, 532-543. [CrossRef]

155. Geng, Y.; Yin, Q.; Liang, Z.; Zhu, H. Polyethyleneimine Cross-Linked Graphene Oxide for Removing Hazardous Hexavalent Chromium: Adsorption Performance and Mechanism. Chem. Eng. J. 2019, 361, 1497-1510. [CrossRef]

156. Zhang, T.; Gao, S.; Si, Q.; Liu, Y.; Wu, G. One-Pot Preparation of P (TA-TEPA)-PAM-RGO Ternary Composite for High Efficient Cr (VI) Removal from Aqueous Solution. Chem. Engineering J. 2018, 343, 207-216. [CrossRef]

157. Guo, Y.; Jia, Z.; Cao, M. Surface modification of graphene oxide by pyridine derivatives for copper (II) adsorption from aqueous solutions. J. Ind. Eng. Chem. 2017, 53, 325-332. [CrossRef]

158. Siu, P.; Koong, L.; Saleem, J.; Barford, J.; McKay, G. Equilibrium and kinetics of copper ions removal from wastewater by ion exchange. Chin. J. Chem. Eng. 2016, 24, 94-100. [CrossRef]

159. Yi, X.; Sun, F.; Han, Z.; Han, F.; He, J.; Ou, M.; Gu, J.; Xu, X. Graphene Oxide Encapsulated Polyvinyl Alcohol/Sodium Alginate Hydrogel Microspheres for Cu (II) and U (VI) Removal. Ecotoxicol. Environ. Saf. 2018, 158, 309-318. [CrossRef] [PubMed]

160. Hayati, B.; Maleki, A.; Najafi, F.; Daraei, H.; Gharibi, F.; McKay, G. Super high removal capacities of heavy metals $\left(\mathrm{Pb}^{2+}\right.$ and $\left.\mathrm{Cu}^{2+}\right)$ using CNT dendrimer. J. Hazard. Mater. 2017, 336, 146-157. [CrossRef] [PubMed]

161. White, R.L.; White, C.M.; Turgut, H.; Massoud, A.; Tian, Z.R. Comparative Studies on Copper Adsorption by Graphene Oxide and Functionalized Graphene Oxide Nanoparticles. J. Taiwan Inst. Chem. Eng. 2018, 85, 18-28. [CrossRef]

162. Zhu, X.; Shan, Y.; Xiong, S.; Shen, J.; Wu, X. Brianyoungite/Graphene Oxide Coordination Composites for High Performance $\mathrm{Cu}^{2+}$ Adsorption and Tunable Deep-Red Photoluminescence. ACS Appl. Mater. Interfaces 2016, 8, 15848-15854. [CrossRef]

163. Chen, D.; Liu, X.; Nie, H. Crumpled Graphene Balls as Rapid and Efficient Adsorbents for Removal of Copper Ions. J. Colloid Interface Sci. 2018, 530, 46-51. [CrossRef]

164. Ranjith, K.S.; Manivel, P.; Rajendrakumar, R.T.; Uyar, T. Multifunctional ZnO nanorod-reduced graphene oxide hybrids nanocomposites for effective water remediation: Effective sunlight driven degradation of organic dyes and rapid heavy metal adsorption. Chem. Eng. J. 2017, 325, 588-600. [CrossRef]

165. Sun, Y.; Lv, S.; Si, C.; Liu, G.; Gao, H. The efficient adsorption removal of $\mathrm{Cu}$ (II) by using $\mathrm{Fe}_{3} \mathrm{O}_{4} / \mathrm{TiO}_{2} / \mathrm{graphene}$ ternary nanocomposites. J. Nanosci. Nanotechnol. 2017, 17, 5400-5407. [CrossRef]

166. Hu, X.-J.; Liu, Y.-G.; Wang, H.; Chen, A.-W.; Zeng, G.-M.; Liu, S.-M.; Guo, Y.-M.; Hu, X.; Li, T.-T.; Wang, Y.-Q. Removal of $\mathrm{Cu}$ (II) ions from aqueous solution using sulfonated magnetic graphene oxide composite. Sep. Purif. Technol. 2013, 108, 189-195. [CrossRef]

167. Yu, R.; Shi, Y.; Yang, D.; Liu, Y.; Qu, J.; Yu, Z.-Z. Graphene oxide/chitosan aerogel microspheres with honeycomb-cobweb and radially oriented microchannel structures for broad-spectrum and rapid adsorption of water contaminants. ACS Appl. Mater. Interfaces 2017, 9, 21809-21819. [CrossRef] [PubMed]

168. Yu, Z.; Chen, Q.; Lv, L.; Pan, Y.; Zeng, G.; He, Y. Attached beta-cyclodextrin/gamma-(2, 3-epoxypropoxy) propyl trimethoxysilane to graphene oxide and its application in copper removal. Water Sci. Technol. 2017, 75, 2403-2411. [CrossRef] [PubMed]

169. Yang, Z.-F.; Li, L.; Hsieh, C.-T.; Juang, R.-S.; Ashraf Gandomi, Y. Fabrication of Magnetic Iron Oxide@Graphene Composites for Adsorption of Copper Ions from Aqueous Solutions. Mater. Chem. Phys. 2018, 219. [CrossRef]

170. Hu, X.; Liu, Y.; Wang, H.; Zeng, G.; Hu, X.; Guo, Y.; Li, T.; Chen, A.; Jiang, L.; Guo, F. Adsorption of copper by magnetic graphene oxide-supported beta-cyclodextrin: Effects of $\mathrm{pH}$, ionic strength, background electrolytes, and citric acid. Chem. Eng. Res. Des. 2015, 93, 675-683. [CrossRef]

171. Sui, N.; Wang, L.; Wu, X.; Li, X.; Sui, J.; Xiao, H.; Liu, M.; Wan, J.; Yu, W. Polyethylenimine modified magnetic graphene oxide nanocomposites for $\mathrm{Cu}^{2+}$ removal. RSC Adv. 2015, 5, 746-752. [CrossRef] 
172. Hosseinzadeh, H.; Ramin, S. Effective removal of copper from aqueous solutions by modified magnetic chitosan/graphene oxide nanocomposites. Int. J. Biol. Macromol. 2018, 113, 859-868. [CrossRef]

173. Yang, P.; Liu, Q.; Liu, J.; Zhang, H.; Li, Z.; Li, R.; Liu, L.; Wang, J. Bovine Serum Albumin-Coated Graphene Oxide for Effective Adsorption of Uranium (VI) from Aqueous Solutions. Ind. Eng. Chem. Res. 2017, 56, 3588-3598. [CrossRef]

174. Tan, L.; Wang, Y.; Liu, Q.; Wang, J.; Jing, X.; Liu, L.; Liu, J.; Song, D. Enhanced adsorption of uranium (VI) using a three-dimensional layered double hydroxide/graphene hybrid material. Chem. Eng. J. 2015, 259, 752-760. [CrossRef]

175. Liu, L.; Liu, S.; Zhang, Q.; Li, C.; Bao, C.; Liu, X.; Xiao, P. Adsorption of Au (III), Pd (II), and Pt (IV) from Aqueous Solution onto Graphene Oxide. J. Chem. Eng. Data 2013, 58, 209-216. [CrossRef]

176. Yan, H.; Li, H.; Tao, X.; Li, K.; Yang, H.; Li, A.; Xiao, S.; Cheng, R. Rapid Removal and Separation of Iron (II) and Manganese (II) from Micropolluted Water Using Magnetic Graphene Oxide. ACS Appl. Mater. Interfaces 2014, 6, 9871-9880. [CrossRef] [PubMed]

177. Liu, L.; Li, C.; Bao, C.; Jia, Q.; Xiao, P.; Liu, X.; Zhang, Q. Preparation and characterization of chitosan/graphene oxide composites for the adsorption of Au (III) and Pd (II). Talanta 2012, 93, 350-357. [CrossRef] [PubMed]

178. Mohammadian, M.; Sahraei, R.; Ghaemy, M. Synthesis and Fabrication of Antibacterial Hydrogel Beads Based on Modified-Gum Tragacanth/Poly (Vinyl Alcohol)/Ag (0) Highly Efficient Sorbent For Hard Water Softening. Chemosphere 2019, 225, 259-269. [CrossRef] [PubMed]

179. Wang, X.; Liu, Y.; Pang, H.; Yu, S.; Ai, Y.; Ma, X.; Song, G.; Hayat, T.; Alsaedi, A.; Wang, X. Effect of Graphene Oxide Surface Modification on the Elimination of Co (II) From Aqueous Solutions. Chem. Eng. J. 2018, 344, 380-390. [CrossRef]

180. Lee, S.P.; Ali, G.A.M.; Algarni, H.; Chong, K.F. Flake Size-Dependent Adsorption of Graphene Oxide Aerogel. J. Mol. Liq. 2019, 277, 175-180. [CrossRef]

181. Guo, L.; Xu, Y.; Zhuo, M.; Liu, L.; Xu, Q.; Wang, L.; Shi, C.; Ye, B.; Fan, X.; Chen, W. Highly Efficient Removal of Gd (III) Using Hybrid Hydrosols of Carbon Nanotubes/Graphene Oxide in Dialysis Bags and Synergistic Enhancement Effect. Chem. Eng. J. 2018, 348. [CrossRef]

182. Liao, M.; Wang, D. Electrosorption of Uranium (VI) by Highly Porous Phosphate-Functionalized Graphene Hydrogel. Appl. Surf. Sci. 2019, 484, 83-96. [CrossRef]

183. Wang, H.; Yuan, X.; Wu, Y.; Huang, H.; Zeng, G.; Liu, Y.; Wang, X.; Lin, N.; Qi, Y. Adsorption characteristics and behaviors of graphene oxide for Zn (II) removal from aqueous solution. Appl. Surf. Sci. 2013, 279, 432-440. [CrossRef]

184. Ramezanzadeh, M.; Asghari, B.; Ramezanzadeh, G. Fabrication of an Efficient System for Zn Ions Removal from Industrial Wastewater Based on Graphene Oxide Nanosheets Decorated with Highly Crystalline Polyaniline Nanofibers (GO-PANI): Experimental and Ab Initio Quantum Mechanics Approaches. Chem. Eng. J. 2018, 337, 385-397. [CrossRef]

185. Ahmed, M.; Elektorowicz, M.; Hasan, S. GO, $\mathrm{Sio}_{2}$, And $\mathrm{Sno}_{2}$ Nanomaterials as Highly Efficient Adsorbents for $\mathrm{Zn}^{2+}$ From Industrial Wastewater-A Second Stage Treatment to Electrically Enhanced Membrane Bioreactor. J. Water Process Eng. 2019, 31. [CrossRef]

(C) 2020 by the authors. Licensee MDPI, Basel, Switzerland. This article is an open access article distributed under the terms and conditions of the Creative Commons Attribution (CC BY) license (http://creativecommons.org/licenses/by/4.0/). 